\title{
KONTAKTY MIĘDZY TOWARZYSTWAMI NAUKOWYMI NA ZIEMIACH POLSKICH POD ZABORAMI - STAN I POTRZEBY BADAŃ
}

Problematyce towarzystw naukowych działających na ziemiach polskich pod zaborami poświęcono już wiele opracowań. Większość $\mathrm{z}$ nich dotyczy historii poszczególnych towarzystw, ujętej w mniejszych lub większych odcinkach czasu. Zdecydowanie najliczniejszą tego typu literaturę mają najważniejsze ówczesne polskie towarzystwa naukowe, czyli Towarzystwo Warszawskie Przyjaciół Nauk ${ }^{1}$, Towarzystwo Naukowe Krakowskie ${ }^{2}$ (dalej: TNK), Akademia Umiejętności ${ }^{3}$ (dalej: AU), Towarzystwo Naukowe Warszawskie ${ }^{4}$ (dalej: TNW)

${ }^{1}$ A. Kraushar, Towarzystwo Warszawskie Przyjaciół Nauk 1800-1832. Monografia historyczna osnuta na źródtach archiwalnych, t. 1-8, Kraków-Warszawa 1900-1906; 200-lecie Towarzystwa Królewskiego Warszawskiego Przyjaciót Nauk, red. Z. Mikulski, Warszawa 2001; referaty z sesji „Dziedzictwo Towarzystwa Królewskiego Warszawskiego Przyjaciół Nauk. Nauka, oświata i kultura polska XIX-XX w.” (Warszawa, 28-29 XI 2000 r.), „Miscellanea Historico-Archivistica” 14, 2002, s. 5-178.

2 J. Majer, Poglad historyczny na Towarzystwo Naukowe Krakowskie z czasu jego zwiazku z Uniwersytetem Jagiellońskim, Kraków 1858; D. Rederowa, Z dziejów Towarzystwa Naukowego Krakowskiego 1815-1872. Kartazhistoriiorganizacji naukipolskiej pod zaborami, Kraków 1998; P. Hübner, Od Towarzystwa Naukowego Krakowskiego do Polskiej Akademii Umiejętności. Refleksje jubileuszowe Mieczystawa Offmańskiego, Tadeusza Sinki, Stanisława Wróblewskiego, Stanisława Kutrzeby, Kraków 2002.

${ }^{3}$ S. Kutrzeba, Polska Akademia Umiejętności 1872-1938, Kraków 1939; J. Hulewicz, Akademia Umiejętności w Krakowie 1873-1918. Zarys dziejów, Wrocław 1958; Materiaty do powstania Akademii Umiejętności w Krakowie w roku 1873, oprac. i przyg. do druku D. Rederowa i K. Stachowska, Wrocław-Kraków 1958; J. Dybiec, Polska Akademia Umiejętności 1872-1952, Kraków 1993; S. Grodziski, Polska Akademia Umiejętności 1872-1952-2002, Kraków 2005. Ta ostatnia publikacja także w języku angielskim: S. Grodziski, The Polish Academy of Arts and Sciences 1872 -1952-2002, Cracow 2006.

${ }^{4}$ B. Nawroczyński, Towarzystwo Naukowe Warszawskie. Materiały do jego dziejów $w$ latach 1907-1950, Warszawa 1950; J. Piskurewicz, L. Zasztowt, Towarzystwo 
czy Poznańskie Towarzystwo Przyjaciół Nauk ${ }^{5}$ (dalej: PTPN). Mimo obszernych studiów na temat tych i innych towarzystw naukowych nie wyczerpano jeszcze i nie rozpoznano wystarczajaco wszystkich aspektów związanych z ich działalnościa. Szczególnie dotkliwe w tym zakresie wydają się trzy luki badawcze.

Pierwsza dotyczy syntetycznego i możliwie pełnego ujęcia historii całego stowarzyszeniowego ruchu naukowego na ziemiach polskich w XIX i na początku XX w. Braku takiej syntezy nie są w stanie wypełnić pojedyncze publikacje ogólne oraz słownikowe, raczej powierzchownie traktujące powyższe kwestie ${ }^{6}$. Tymczasem wypracowanie swego rodzaju kompendium historii towarzystw naukowych na ziemiach polskich pod zaborami umożliwiłoby nie tylko szersze spojrzenie na ich złożona problematykę, ale także ułatwiłoby zrozumienie specyfiki poszczególnych towarzystw i różnic, jakie zarysowały się na polu naukowym w trzech zaborach.

Druga wspomniana przeze mnie luka badawcza w historiografii polskiej wynika z dość jednostronnego postrzegania do tej pory dziejów towarzystw naukowych na ziemiach polskich, głównie przez pryzmat polskich środowisk i organizacji. W dużo mniejszym stopniu zajmowano się natomiast dotąd niemieckimi, litewskimi czy ukraińskimi towarzystwami naukowymi na ziemiach polskich. Do wyjątków należą tu publikacje: Magdaleny Niedzielskiej i Macieja Szukały, poświęcone niemieckim towarzystwom, oraz Henryki Ilgiewicz, specjalizującej się w historii instytucji naukowych na Litwie?

Naukowe Warszawskie, „Rocznik Towarzystwa Naukowego Warszawskiego” 49, 1986 [druk 1990], s. 35-103; Towarzystwo Naukowe Warszawskie. Sto lat działalności, red. E. Wolnicz-Pawłowska i W. Zycha, Warszawa 2009.

${ }^{5}$ A. Wojtkowski, Towarzystwo Przyjaciół Nauk w Poznaniu w latach 1857-1927, „Roczniki Poznańskiego Towarzystwa Przyjaciół Nauk” 50, 1928, s. 3-536; Księa pamiatkowa $w$ stulecie Poznańskiego Towarzystwa Przyjaciót Nauk, „Roczniki Historyczne" 23, 1957, s. 311-559; Sto lat Poznańskiego Towarzystwa Przyjaciót Nauk. Album, red. M. Wojciechowska, Poznań 1957; Veritate et scientia. Ksiega pamiatkowa $w$ 125-lecie Poznańskiego Towarzystwa Przyjaciót Nauk, red. A. Gassiorowski, Warszawa-Poznań 1982; B. Piotrowski, Poznańskie Towarzystwo Przyjaciót Nauk. W stużbie narodu i nauki 1857-1918, Poznań 1983; R. Marciniak, 125 lat w stużbie nauki 1857-1982, Poznań 1982.

${ }^{6}$ W. Rolbiecki, Towarzystwa naukowe w Polsce, Warszawa 1972; S. Kunikowski, Towarzystwa naukowe ogólne w Polsce w XIX i XX wieku, Włocławek 1999; Towarzystwa naukowe $i$ upowszechniajace naukę działajace $w$ przeszłości na ziemiach polskich, red. B. Sordylowa, cz. 1, Wrocław 1990, cz. 2, Warszawa 1994, cz. 3, Warszawa 2001; J. Maślanka, Nauka i niepodległość. O polskich towarzystwach naukowych pod zaborami, „Rocznik Biblioteki Naukowej PAU i PAN w Krakowie” 55, 2010, s. 215-227.

${ }^{7}$ M. Niedzielska, Dzieje toruńskiego towarzystwa Coppernicus-Verein für Wissenschaft und Kunst (1853-1945), „Rocznik Toruński” 16, 1983, s. 113-152; taż, Niemiec- 
Trzecia wreszcie słaba strona polskiej historiografii $\mathrm{w}$ omawianej tu dziedzinie odnosi się do wzajemnych kontaktów i form współpracy, jakie nawiązały ze sobą i utrzymywały towarzystwa naukowe na ziemiach polskich w XIX i na początku XX w. Bardzo słabo zbadane są też relacje polskich towarzystw naukowych z odpowiadajacymi im organizacjami europejskimi, spoza obszaru trzech państw zaborczych. Wprawdzie wątki kontaktów naukowych między towarzystwami pojawiają się $\mathrm{w}$ dotychczasowej literaturze przedmiotu, ale przeważnie $\mathrm{w}$ postaci szczątkowej, sygnalizującej jedynie ten problem. Jest to zwłaszcza widoczne $\mathrm{w}$ monografiach poszczególnych towarzystw. W kilku przypadkach dysponujemy jednak bardziej szczegółowymi rozprawami poświęconymi temu zagadnieniu. Chodzi tu mianowicie o prace: Danuty Rederowej i Krystyny Stachowskiej, zajmujących się pod tym względem historia AU, Marii M. Blombergowej, ukazującej kontakty Polaków z rosyjskimi instytucjami naukowymi, oraz Ryszarda Marciniaka, opisującego z tego punktu widzenia PTPN ${ }^{8}$. Doceniając wkład tych autorów w badania nad współpraca między towarzystwami, trzeba podkreślić, że ciagle zbyt mało wiemy o tych sprawach. A przecież sa one niezwy-

kie towarzystwa naukowe w Prusach Zachodnich w latach 1815-1920, Toruń 1993; taż, Niemieckie towarzystwa naukowe w Prusach Zachodnich - historia polityczna, w: Poznańskie Towarzystwo Przyjaciót Nauk a towarzystwa naukowe na ziemiach polskich w XIX i na poczatku XX wieku, red. W. Molik, A. Hinc, w druku; M. Szukała, Powstanie i działalność Towarzystwa Historii $i$ Starożytności Pomorza $w$ Szczecinie w latach 1824-1918. Z dziejów pomorskiej nauki i kultury XIX i poczqtku XX wieku, Szczecin 2000; H. Ilgiewicz, Wileńskie towarzystwa i instytucje naukowe w XIX wieku, Toruń 2005.

${ }^{8}$ D. Rederowa, Ze studiów nad kontaktami Akademii Umiejętności z nauka obca. Ekspedycja Rzymska (1886-1918), „Rocznik Biblioteki Polskiej Akademii Nauk w Krakowie” (dalej: „Rocznik B. PAN K.”) 4, 1958, s. 191-256; taż, Formy wspótpracy Polskiej Akademii Umiejętności z zagranica (1873-1952), „Studia i Materiały z Dziejów Nauki Polskiej”, Seria A, Historia Nauk Społecznych, z. 10, 1966, s. 77-131; taż, Polska Stacja Naukowa w Paryżu (1893-1926), w: D. Rederowa, B. Jaczewski, W. Rolbiecki, Polska Stacja Naukowa w Paryżu w latach 1893-1978, przedm. A.F. Grabski, Wrocław 1982, s. 43-150; K. Stachowska, Kontakty Polskiej Akademii Umiejętności z naukq szwedzkq w latach 1873-1952, „Rocznik B. PAN K.” 24, 1978/1979, s. 109-124 (ostatnia publikacja także w języku angielskim: K. Stachowska, Polish-Swedish Contacts in the Activities of the Polish Academy of Sciences and Letters 1872-1952, „Zeszyty Naukowe Uniwersytetu Jagiellońskiego", Prace Historyczne, z. 61, 1979, s. 107-122); M.M. Blombergowa, Polscy członkowie rosyjskich towarzystw archeologicznych 1839 -1914, Wrocław 1988; taż, Kontakty polskich starożytników i archeologów z rosyjskimi instytucjami naukowymi w Odessie (do 1914 r.), „Kwartalnik Historii Nauki i Techniki” 40, 1995, nr 4, s. 33-47; taż, Kontakty Polaków z Cesarskim Rosyjskim Towarzystwem Archeologicznym $w$ Petersburgu, „Analecta” 12, 2003, z. 1-2, s. 147-163; R. Marciniak, Zwiqzki Poznańskiego Towarzystwa Przyjaciót Nauk z polskimi ośrodkami naukowymi w okresie zaborów, „Prace Komisji Historii Nauki” 8, 2007, s. 275-315. 
kle ważne nie tylko dla odtworzenia kondycji nauki polskiej uprawianej i upowszechnianej przez towarzystwa w XIX i na początku XX w., ale także dla prawidłowej ich oceny w zestawieniu z innymi towarzystwami naukowymi działającymi zarówno w trzech państwach zaborczych, jak i poza nimi. O prestiżu i znaczeniu towarzystw naukowych świadczyły bowiem i świadczą nadal właśnie przede wszystkim różnorodne kontakty, mające na celu wymianę doświadczeń badawczych oraz inicjowanie i w miarę możliwości prowadzenie wspólnych przedsięwzięć.

Pisząc o kontaktach między różnymi instytucjami naukowymi działajacymi na ziemiach polskich w XIX i na początku XX w., warto zaznaczyć, że wkraczamy na rozległy i wielopłaszczyznowy obszar badań. Wynika to nie tylko z faktu bogactwa problematyki historii nauki jako takiej, ale przede wszystkim ze szczególnych warunków, w jakich funkcjonowała nauka polska w omawianym okresie. Przypomnijmy, że wraz z rozbiorami Polski, w końcu XVIII w. główne polskie ośrodki kultury i nauki znalazły się w trzech odmiennych systemach politycznych. W każdym $\mathrm{z}$ nich współistniały one $\mathrm{z}$ różnorodnymi etnicznie organizacjami naukowymi, m.in. austriackimi, czeskimi, węgierskimi, ukraińskimi, rosyjskimi, litewskimi, niemieckimi. Powstała w ten sposób prawdziwa mozaika etnicznie zróżnicowanych organizacji naukowych, które, jak można sądzić, wzajemnie na siebie oddziaływały. Na czym polegało to oddziaływanie i jakie były jego rezultaty? Jakie zataczało ono kręgi i co determinowało współpracę naukową między towarzystwami - czy były to podobieństwa narodowościowo-kulturowe, czy funkcjonowanie raczej $\mathrm{w}$ ramach jednego organizmu państwowego? $\mathrm{Na}$ ile działanie na rzecz nauki przekraczało granice państw? Jaka rolę odgrywały $\mathrm{w}$ tym procesie towarzystwa naukowe? To tylko niektóre z nasuwających się $\mathrm{w}$ tym miejscu pytań. Warto także rozważyć, w jakim stopniu poszczególne towarzystwa naukowe działajace na ziemiach polskich w XIX i na początku XX w. zabiegały o kontakty między sobą i co je do tego skłaniało? Które towarzystwa ze sobą rywalizowały, a które ściśle współpracowały? Czy polskie środowiska naukowe potrafiły wykorzystać pojawiające się możliwości współpracy międzyzaborowej oraz na ile była ona inspirowana przez prywatne kontakty niektórych przedstawicieli nauki? Jakie $\mathrm{w}$ istocie było znaczenie tych kontaktów i jaką rolę odgrywała w nich polityka? Czy polskie, niemieckie, litewskie i ukraińskie towarzystwa naukowe na ziemiach polskich pod zaborami oddziaływały na siebie w zakresie forsowanych badań naukowych oraz publikowanych prac?

W niniejszym artykule nie znajdzie czytelnik odpowiedzi na wszystkie powyższe pytania, ponieważ aby ich udzielić, należałoby przeprowadzić 
dalsze, szczegółowe badania w tej dziedzinie. Publikacja ta ma natomiast na celu, poza nakreśleniem ogólnego obrazu kontaktów między towarzystwami naukowymi działajacymi na ziemiach polskich pod zaborami, przedstawienie dotychczasowego stanu badań nad tym niezwykle obszernym tematem oraz wskazanie jawiących się w jego obrębie perspektyw badawczych. Być może zainspiruja one w przyszłości historyków do podjęcia dalszych studiów w tym zakresie, dla których punktem wyjścia powinna być dobra znajomość infrastruktury naukowej i majacej na nią istotny wpływ sytuacji politycznej panującej w każdym z trzech zaborów.

\section{Zabór pruski}

Krótką charakterystykę warunków, w jakich toczyło się szeroko rozumiane życie umysłowe na ziemiach polskich w omawianym okresie, rozpocząc wypada od zaboru pruskiego, ponieważ na jego obszarze powstało pierwsze polskie towarzystwo naukowe.

Po III rozbiorze Polski zabór pruski charakteryzował się umiarkowanymi możliwościami rozwijania ruchu naukowego. Przede wszystkim na zagarniętych wówczas przez Prusy rozległych terenach Polski nie było żadnego ośrodka uniwersyteckiego. Wprawdzie władze pruskie nosiły się z zamiarem utworzenia w jednym $\mathrm{z}$ nowo zajętych miast uniwersytetu (w grę wchodziły: Toruń, Chełmno i Rydzyna), ale z uwagi na brak funduszy i dominujący coraz bardziej pogląd, że młodzież polska powinna studiować na niemieckich uczelniach, nigdy nie zrealizowały tego pomysłu? .

Wobec tego kluczową rolę w kształtowaniu życia umysłowego w zaborze pruskim pełniła, przez ponad dekadę (1795-1806), Warszawa, która za czasów Stanisława Augusta Poniatowskiego stała się prawdziwym centrum kultury polskiej. Właśnie z Warszawy, choć ranga tego miasta pod panowaniem pruskim znacznie spadła, wyszły pierwsze zakładające współpracę międzyzaborową inicjatywy naukowe. Tamtejszym elitom polskim, szczególnie aktywnym po rozbiorach na polu narodowym, udało się bowiem, mimo początkowej podejrzliwości władz, uzyskać zezwolenie na założenie w 1800 r. pierwszego towarzystwa naukowego na ziemiach polskich. Nadano mu nazwę Warszawskie Towarzystwo Przyjaciół Nauk. Jednym z głównych założeń twórców

${ }_{9}^{9}$ J. Michalski, Warunki rozwoju nauki polskiej, w: Historia nauki polskiej, red. B. Suchodolski, t. 3: 1795-1862, red. J. Michalski, Wrocław 1977, s. 11. 
Towarzystwa było skupienie w jego ramach możliwe szerokiego grona intelektualistów polskich, którzy rozproszeni w trzech zaborach działaliby wspólnie na rzecz nauki i kultury ojczystej. Na członków Towarzystwa powołano więc przedstawicieli różnych środowisk umysłowych, najczęściej legitymujących się już pewnym dorobkiem, z czterech najważniejszych ośrodków: Warszawy, Krakowa, Wilna i Lwowa. Wśród nich znaleźli się m.in.: Ignacy Krasicki, Franciszek Karpiński czy Jan Śniadecki. Oprócz tego szeregi Towarzystwa zasilili także liczni reprezentanci arystokracji i bogatego ziemiaństwa. Politykę Towarzystwa wytyczali jednak najwybitniejsi jego założyciele, do których należeli m.in.: Tadeusz Czacki, Stanisław Staszic, Stanisław Potocki i Jan Albertrandi. Oni też zauważyli z czasem, że mimo ambitnych planów elity pozawarszawskie słabo angażowały się $\mathrm{w}$ prace Towarzystwa. $\mathrm{W}$ związku z tym przyjęto $\mathrm{w} 1803 \mathrm{r}$. zasadę przyznawania pierwszeństwa przy wyborach nowych członków dla kandydatów miejscowych ${ }^{10}$. Nie powiodły się też specjalnie, w pierwszych latach działania Towarzystwa, próby nawiązania przez nie kontaktów zagranicznych. Być może wynikało to $\mathrm{z}$ bardzo narodowego charakteru Towarzystwa, które stawiało sobie za cel pielęgnowanie języka polskiego, kultywowanie rodzimej przeszłości i publikowanie rozpraw mogacych przynieść pożytek krajowi. Silne akcentowanie tych elementów przez nowe, nieznane jeszcze Towarzystwo oraz ogólnie słaba pozycja polskich elit, niemajacych po rozbiorach oparcia w państwie, mogło wpływać hamująco na znalezienie zagranicznej organizacji naukowej zainteresowanej współpracą. Łatwiej było niewątpliwie pozyskać Towarzystwu na członków wybranych cudzoziemców wyróżniających się pod względem naukowym lub artystycznym. W sumie powstałe w czasach pruskich Warszawskie Towarzystwo Przyjaciół Nauk zapoczątkowało na ziemiach polskich nowy kierunek uprawiania i upowszechniania szeroko rozumianej nauki polskiej. Stworzyło też podstawy do rozwijającej się później współpracy międzyzaborowej, prowadzonej w myśl hasła „nauka w służbie ojczyzny".

Jak wiadomo, po 1806 r. zabór pruski uległ znacznemu zmniejszeniu, co związane było ze zwycięską kampania Napoleona i utworzeniem Księstwa Warszawskiego. Wprawdzie późniejsza klęska Napoleona i nowy podział ziem polskich na kongresie wiedeńskim sprawiły, że Prusy ponownie zajęły większą część Wielkopolski, tworząc na jej terenie prowincję o nazwie Wielkie Księstwo Poznańskie oraz południowy odcinek Pomorza Gdańskiego włączony do Prus Zachodnich,

10 Tamże, s. 13. 
ale był to ciagle dużo mniejszy obszar w porównaniu z nabytkami pruskimi po trzech rozbiorach. Pisząc więc o zaborze pruskim po 1815 r., mamy na myśli Wielkie Księstwo Poznańskie i Prusy Zachodnie, które w latach 1829-1878 połaczone były administracyjnie z Prusami Wschodnimi, stanowiąc jedna prowincję.

Pod względem infrastruktury naukowej sytuacja w tych prowincjach wyglądała kiepsko. Przede wszystkim brakowało w nich, podobnie jak poprzednio, uniwersytetu. Co gorsza, nie było nawet specjalnie szans na jego powołanie, ponieważ władze pruskie nie widziały już wówczas takiej potrzeby. W ogóle nie były one zainteresowane kulturalnym czy naukowym rozwojem dawnych polskich ziem. Z czasem utwierdziły się nadto w przekonaniu, że lepiej będzie dla państwa, gdy młodzież polska z Poznańskiego i Prus Zachodnich ewentualne wyższe wykształcenie zdobędzie na uczelniach niemieckich. Władze pruskie chciały bowiem przez to osiagnąc możliwie głęboką integrację młodzieży polskiej z państwem pruskim. Zupełnie odmienne cele przyświecały z kolei elitom polskim, które przez cały właściwie w. XIX podejmowały starania o utworzenie uniwersytetu w Poznaniu - jednym z głównych miast zaboru pruskiego. Koła rządowe w Berlinie odrzucały jednak każdorazowo polskie petycje w tej sprawie, argumentując swoje decyzje zawsze jednakowo, tzn. trudnościami finansowymi i mała liczebnościa młodzieży uzyskującej maturę w Poznańskiem i mogacej tym samym rozpoczać studia ${ }^{11}$. Ten drugi stan rzeczy wynikał zreszta z celowego hamowania przez władze rozwoju szkolnictwa średniego w zaborze, zwłaszcza w regionach, gdzie przeważała liczebnie ludność polska.

Jedynymi wyższymi uczelniami, które powstały ostatecznie w zaborze pruskim, były Akademia Królewska w Poznaniu, Wyższa Szkoła Techniczna w Gdańsku i Wyższa Szkoła Muzyczna w Bydgoszczy. Ich otwarcie zainspirowane zostało przez środowiska niemieckie, które od końca XIX w. coraz bardziej zdawały sobie sprawę z roli, jaką mogłaby odegrać wyższa uczelnia $\mathrm{w}$ podniesieniu prestiżu wschodnich prowincji Prus. Zadanie takie przypisano m.in. założonej w 1903 r. Akademii Królewskiej w Poznaniu, realizującej misje szerzenia kultury niemieckiej w prowincji poznańskiej. Akademia Królewska nie otrzymała jednak nigdy statusu uniwersytetu i nie wpłynęła znacząco na wzrost

${ }^{11}$ Więcej na temat polskich zabiegów o założenie uniwersytetu w Poznaniu S.Z. Gołębiowski, Starania polskie o uniwersytet $w$ Poznaniu $w$ XIX wieku, „Studia i Materiały do Dziejów Wielkopolski i Pomorza" 3, 1957, z. 2, s. 29-58; Z. Grot, Czterysta lat walki o uniwersytet w Poznaniu, w: Dzieje Uniwersytetu im. Adama Mickiewicza 1919-1969, Poznań 1972, s. 9-58. 
nauki niemieckiej w zaborze pruskim ${ }^{12}$. Z tego punktu widzenia znacznie silniejszą pozycję miała niewątpliwie, otwarta w 1904 r., Wyższa Szkoła Techniczna w Gdańsku, która wyspecjalizowała się dość szybko w kształceniu kadr zajmujących się budownictwem okrętowym. Warto podkreślić, że obok politechniki berlińskiej była ona największym ośrodkiem w Niemczech szkolącym tego typu inżynierów ${ }^{13}$. Najpóźniej powołana do życia, w 1907 r., Wyższa Szkoła Muzyczna w Bydgoszczy, choćby przez jej specyficzny charakter, w najmniejszym stopniu przyczyniła się do rozbudzenia życia naukowego w zaborze pruskim.

Wszystkie te czynniki bardzo niekorzystnie odbiły się na kondycji życia umysłowego w tym zaborze i spowodowały, że nie wykształciły się w nim, przez cały w. XIX, większe skupiska profesjonalnych badaczy, zarówno narodowości polskiej, jak i niemieckiej. Nieliczne kręgi naukowe, które istniały, składały się w dużej mierze z nauczycieli gimnazjalnych, zgłębiających $\mathrm{w}$ wolnym czasie tajniki reprezentowanej przez nich dziedziny wiedzy ${ }^{14}$. Swe osiagnięcia czy prace naukowe publikowali oni początkowo na łamach prasy lub w sprawozdaniach rocznych wydawanych przez szkołę, w której pracowali. Najbardziej aktywni nauczyciele szukali współpracy z innymi badaczami i miejsca służącego do prezentacji ich dokonań. Z tej potrzeby zrodziła się idea utworzenia w 1837 r. pierwszego niemieckiego towarzystwa naukowego w zaborze pruskim, noszącego nazwę Naturwissenschaftlicher Verein der Provinz Posen ${ }^{15}$. Jego założycielem był Hermann Loew, nauczyciel z Gimnazjum Fryderyka Wilhelma w Poznaniu, botanik i entomolog. Celem towarzystwa było zbadanie prowincji poznańskiej pod katem przyrodniczym oraz popularyzacja wiedzy przyrodniczej w społeczeństwie. W swoich szeregach gromadziło ono polskich i niemieckich nauczycieli gimnazjalnych oraz reprezentantów innych zawodów

${ }^{12}$ Ch. Schutte, Die Königliche Akademie in Posen (1903-1919) und andere kulturelle Einrichtungen im Rahmen der Politik zur „Hebung des Deutschtums”, Marburg 2008.

${ }^{13}$ R. Ruhnau, Technische Hochschule Danzig 1904-1984, Stuttgart 1985.

${ }^{14}$ Zob. K. Makowski, Polskie środowisko naukowe $w$ szkołach średnich $w$ okresie zaborów, w: Alma Mater Posnaniensis. W 80. rocznice utworzenia uniwersytetu $w$ Poznaniu, red. P. Hauser, T. Jasiński i J. Topolski, Poznań 1999, s. 97-105.

${ }^{15}$ Nie licząc założonego w Gdańsku w 1743 r., czyli jeszcze w czasach I Rzeczypospolitej, towarzystwa naukowego o nazwie Societas Physicae Experimentalis, znanego później pod niemieckim mianem Naturforschende Gesellschaft. Było ono jedynym spośród osiemnastowiecznych towarzystw gdańskich, które przetrwało zmiany polityczne spowodowane rozbiorami Polski, działając przez cały w. XIX, a w XX - aż do końca II wojny światowej. Zob. M. Niedzielska, Niemieckie towarzystwa naukowe w Prusach Zachodnich w latach 1815-1920..., s. 21-40. 
inteligenckich zainteresowanych przyroda. Przez wiele lat towarzystwo przyrodnicze nie nawiązało żadnych relacji naukowych z innymi, podobnymi organizacjami. Dopiero w 1875 r. zawarło umowę z miejscowym towarzystwem politechnicznym, na mocy której członkowie obu towarzystw mogli uczestniczyć w posiedzeniach naukowych partnerskiej instytucji. Dodatkowo członkowie towarzystwa politechnicznego mogli korzystać z bogatej biblioteki towarzystwa przyrodniczego ${ }^{16}$. To ostatnie miało być może w okresie późniejszym szersze kontakty (w 1902 r. przekształciło się w Wydział Przyrodniczy Deutsche Gesellschaft für Kunst und Wissenschaft in Posen), ale nie zmienia to faktu, że było ono typowo prowincjonale. Na gruncie lokalnym należało jednak do nielicznych utrzymujacych i rozwijajacych we własnym gronie, przynajmniej do lat 80. XIX w., polsko-niemieckie relacje naukowe ${ }^{17}$. Było przy tym najdłużej czynnym niemieckim towarzystwem naukowym w prowincji poznańskiej.

Dwadzieścia lat trzeba było czekać na zawiazanie się kolejnego, tym razem wyłącznie polskiego, towarzystwa naukowego w Poznańskiem. Pomysł jego założenia pojawił się w 1856 r. i wyszedł od Kazimierza Szulca, świeżo doktoryzowanego na uniwersytecie wrocławskim historyka i geografa, który przybył właśnie do Poznania, by objąć posadę nauczycielska. Poczatkowo myślał on - wraz z ks. Franciszkiem Malinowskim - o powołaniu stowarzyszenia na wzór Maticy czeskiej, czyli organizacji mającej charakter masowy, zajmującej się popieraniem i upowszechnianiem nauki czeskiej. Nie znalazł jednak dla swojej idei specjalnego uznania w tutejszym środowisku inteligencji polskiej, która jeśli już gotowa była zaangażować się w to przedsięwzięcie, opowiadała się raczej za instytucja nawiąująca tradycjami do Warszawskiego Towarzystwa Przyjaciół Nauk, a więc skupiającego wybrane grono badaczy ${ }^{18}$. Mimo różnych oporów i koncepcji udało się ostatecznie 12 I 1857 r. utworzyć na zebraniu konstytucyjnym, w którym wzięły udział 42 osoby, PTPN ${ }^{19}$.

${ }^{16}$ A. Magener, Geschichte des Naturwissenschaftlichen Vereins der Provinz Posen, w: Festschrift zum fünfzigjährigen Jubiläum des Naturwissenschaftlichen Vereins der Provinz Posen, 1837 bis 1887, Posen 1887, s. 13-14.

${ }^{17}$ Zob. W. Molik, Z dziejów polsko-niemieckich kontaktów naukowych. Niemieckie Towarzystwo Naukowe Przyrodników w Poznaniu i udziat Polaków w jego działalności (1837-1902), w: Rola Wielkopolski $w$ dziejach narodu polskiego, red. S. Kubiak i L. Trzeciakowski, Poznań 1979, s. 161-171.

${ }^{18}$ L. Trzeciakowski, $W$ dobie rozbiorowej, w: Veritate et scientia..., s. 14.

${ }^{19}$ Należy w tym miejscu zaznaczyć, że nazwa Towarzystwa zmieniała się z biegiem czasu. Pierwotnie brzmiała ona: Towarzystwo Przyjaciół Nauk Poznańskie. W 1907 r. w ustawach organizacji zapisano nazwę Towarzystwo Przyjaciół Nauk w Poznaniu. 
Pierwszym jego prezesem obrany został znany filozof i ziemianin August Cieszkowski. Pod względem przekroju społecznego do Towarzystwa należeli przede wszystkim ziemianie oraz nieliczna wówczas $\mathrm{w}$ prowincji poznańskiej inteligencja. Towarzystwo opierało się zatem bardziej na miłośnikach nauki niż profesjonalnych uczonych. Za główny cel postawiło sobie „pielęgnowanie nauk i umiejętności w języku polskim”, co zamierzało osiagnać m.in. poprzez gromadzenie i publikowanie różnorodnych materiałów dotyczacych historii oraz literatury narodowej. Odżegnywało się świadomie od poruszania jakiejkolwiek problematyki politycznej, by nie prowokować ingerencji władz zaborczych w sprawy Towarzystwa. Niezależnie jednak od tego władze pruskie z niechęcią przyjęły samo powstanie nowego stowarzyszenia Polaków i podjęły różne działania, by osłabić ich aktywność. Najbardziej dotkliwą reakcją władz na zawiązanie się Towarzystwa było najpierw zdecydowane odradzanie udzielania się w nim nauczycielom gimnazjalnym, a następnie wydanie w 1866 r. oficjalnego zakazu przynależności do niego urzędnikom państwowym i profesorom gimnazjalnym ${ }^{20}$. Dla Towarzystwa oznaczało to poważne ograniczenie możliwości prowadzenia życia naukowego, ponieważ nauczyciele gimnazjalni, wobec braku uniwersytetu w Poznaniu, stanowili podstawę tutejszego środowiska intelektualnego. Cieszkowski zastanawiał się nawet nad zawieszeniem działalności PTPN, ale powstrzymali go przed tym pozostali jego członkowie. Przezwyciężyli oni wszelkie trudności ze strony władz i kontynuowali nieprzerwanie do końca zaborów, a także i później, swoje prace. Finansowali się z własnych składek oraz różnych darów zamożnych Polaków, którym zależało na dobrym funkcjonowaniu Towarzystwa. Na dotacje państwowe nie mogło wszakże PTPN zupełnie liczyć.

Wśród pierwszych partnerów naukowych, z którymi towarzystwo poznańskie zadzierzgnęło kontakty międzyzaborowe, było istniejące od 1815 r. TNK, różniące się wyraźnie od PTPN swoim akademickim charakterem. Bardzo krótko pisała na ten temat w jednej ze swoich publikacji Maria Stinia, zwracając uwagę, że pierwotne, nieformalne jeszcze, związki między obu towarzystwami można już dostrzec w okresie prezesury Cieszkowskiego, angażującego się od czasów studiów w Krakowie w prace na rzecz TNK oraz wspierającego je także

Z kolei w 1923 r. w nowym statucie Towarzystwa przyjęto nazwę Poznańskie Towarzystwo Przyjaciół Nauk, która funkcjonuje do dziś. W związku z tym, że jest ona powszechnie używana, także w opisach minionych czasów, autorka artykułu postanowiła posługiwać się nią konsekwentnie w odniesieniu do całości dziejów Towarzystwa.

${ }^{20}$ L. Trzeciakowski, dz. cyt., s. 20. 
materialnie ${ }^{21}$. Faktyczną współpracę między PTPN a TNK rozpoczął jednak drugi prezes towarzystwa poznańskiego, Tytus Działyński, niezwykle zasłużony dla kultury polskiej ziemianin, twórca wspaniale wyposażonej Biblioteki Kórnickiej. Jako osoba mająca bardzo rozległe kontakty międzyzaborowe zdawał sobie zapewne Działyński sprawę z potrzeby współdziałania PTPN z innymi ośrodkami naukowymi. Konieczność wchodzenia $\mathrm{w}$ relacje $\mathrm{z}$ różnymi towarzystwami akcentowali też przedstawiciele towarzystwa krakowskiego. Dwaj z nich, Karol Kremer i Jan Kanty Rzesiński w 1851 r. w piśmie do władz TNK przekonywali: „Każde towarzystwo naukowe o tyle tylko stanie się ogniskiem krajowej oświaty i na stanowisku, jakie naukowość w ogóle zajmuje, utrzymać się potrafi, o ile wejdzie w związki z innymi tegoż samego rodzaju towarzystwami krajowymi i zagranicznymi i pomiędzy swych współpracowników jak największą liczbę znakomitych nauką mężów policzy. Nie zawiąże zaś stosunków z innymi towarzystwami, nie wzbudzi współczucia [tj. zainteresowania R.M.] między uczonymi, jeżeli ich ze swą dążnościa, z owocem swych prac nie obznajomi" ${ }^{2}$.

Efektem tak otwartego nastawienia obu towarzystw na wymianę doświadczeń naukowych były wspólne przedsięwzięcia. W $1858 \mathrm{r}$. zarzą PTPN przesłał wybrane eksponaty archeologiczne, gromadzone w założonym przy towarzystwie poznańskim Muzeum Starożytności Polskich i Słowiańskich, na wystawę starożytności w Krakowie, organizowana przez TNK. Analogiczną wymianę planowano również na rok 1863, w którym miała się odbyć wystawa starożytności w Poznaniu, ale udaremniła ją wówczas trudna sytuacja polityczna (powstanie styczniowe w zaborze rosyjskim). Udało się natomiast towarzystwu poznańskiemu zainicjować wzorem towarzystwa krakowskiego i przy jego wsparciu prace badawczo-inwentaryzacyjne i konserwatorskie nad zabytkami architektury kościelnej i ruinami na Ostrowie Lednickim ${ }^{23}$. Ponadto, od 1859 r., czyli bardzo wcześnie, PTPN i TNK ustaliły między sobą wzajemną wymianę pism i duplikatów ze zbiorów starożytności polskich ${ }^{24}$. Generalnie trzeba tu podkreślić, że wymienianie się różnymi publikacjami, w tym wydawnictwami własnymi i sprawozdaniami

${ }^{21}$ M. Stinia, Zwiazki naukowe Poznańskiego Towarzystwa Przyjaciót Nauk z ośrodkiem krakowskim $w$ XIX $i$ na poczatku XX wieku, w: Poznańskie Towarzystwo Przyjaciót Nauk a towarzystwa naukowe...

${ }^{22}$ Cyt. za R. Marciniak, Zwiazki Poznańskiego Towarzystwa Przyjaciót Nauk..., s. 283.

${ }^{23}$ J. Michalski, dz. cyt., s. 320.

${ }^{24}$ R. Marciniak, Zwiazki Poznańskiego Towarzystwa Przyjaciót Nauk..., s. 289. 
z działalności, było najbardziej trwałą i podstawową formą współpracy PTPN nie tylko z towarzystwem krakowskim.

Przekształcenie tego ostatniego w 1872 r. w AU z jednej strony otworzyło nowy etap wzajemnych stosunków między PTPN a ośrodkiem krakowskim, a z drugiej strony stanowiło kontynuację prowadzonej poprzednio współpracy. Problematyce tej znacznie więcej miejsca poświęciła we wspomnianej publikacji Stinia ${ }^{25}$, która wskazała przede wszystkim na wiodąca rolę AU w podtrzymywaniu międzyzaborowych kontaktów naukowych i promieniowanie jej osiagnięć na pozostałe ziemie polskie. Stwierdziła także, że relacje naukowe na linii PTPN a AU układały się do końca okresu zaborów bardzo różnie. Dominowała niewątpliwie szeroko rozumiana wymiana wydawnicza. Z czasem dołaczyły do niej pojedyncze inicjatywy wspólnej pracy nad edycjami źródeł do historii Polski oraz organizowane głównie przez AU zjazdy naukowe, na które zapraszano reprezentantów PTPN (np. Zjazd im. Jana Długosza z 1880 r., Zjazd im. Jana Kochanowskiego z 1884 r. czy Zjazd im. Mikołaja Reja z 1906 r. ${ }^{26}$. Co ciekawe, właśnie owe zjazdy naukowe obnażyły w pewien sposób nie do końca dobrze przebiegająca współpracę poznańskiego środowiska naukowego z krakowskim. Świadczy o tym m.in. list sekretarza generalnego AU Józefa Szujskiego do prezesa PTPN Stanisława Egberta Koźmiana z r. 1880. Czytamy w nim mianowicie: „Jak dotąd stosunki z Wielkopolska, powiedzmy prawdę, należą do słabszych. Mamy tu w Krakowie więcej relacji z Podolem i Ukraina, jak z Poznańskiem. Dlaczego? Nie chcę w to wchodzić; zdaje mi się jednak, że istnieje tam pewna nieufność ku temu, co krakowskie [...], a robimy to wszystko, jak umiemy i jak nas stać, jak stać prowincję do $1861 \mathrm{r}$. najgorzej traktowana" ${ }^{27}$.

Szujski apelował więc dalej w liście o wykazanie większego zainteresowania sprawami krakowskimi przez rodaków z Poznańskiego i Królestwa Polskiego. Jego sugestie nie przyniosły chyba specjalnie rezultatu, zważywszy na nieliczny w sumie udział delegacji poznańskiej we wspomnianych wyżej zjazdach naukowych, na których żaden z delegowanych nie wygłosił swojego referatu. Trudno jednoznacznie powiedzieć, co było tego przyczyną: ogólna słabość poznańskiego środowiska naukowego, rodzaj obojętności w nim panującej wobec inicjatyw $\mathrm{z}$ zewnątrz i zaniedbania $\mathrm{w}$ ich popieraniu czy jeszcze inne względy.

${ }^{25}$ M. Stinia, dz. cyt.

${ }^{26}$ Więcej na temat zjazdów - J. Hulewicz, Akademia Umiejętności w Krakowie..., s. $138-145$.

${ }^{27}$ Cyt. za R. Marciniak, Zwiazki Poznańskiego Towarzystwa Przyjaciót Nauk..., s. 285. 
Kwestia ta wymaga na pewno dodatkowego zbadania. Niewykluczone także, że narzekania Szujskiego na brak pobudzających impulsów płynących z Poznańskiego i Królestwa Polskiego były przesadzone.

$\mathrm{Na}$ tym tle bardzo korzystnie wypadają kontakty naukowe między Wydziałem Lekarskim PTPN a środowiskiem medycznym w Krakowie. Sięgają one początków zawiązania się w grudniu 1865 r. Sekcji Lekarskiej przy PTPN, która poinformowała od razu o swoim istnieniu prezesa TNK, profesora Józefa Majera, oraz prezesa Towarzystwa Lekarskiego Warszawskiego, dr. Jakuba Natansona ${ }^{28}$. Następnie nawiazała ona relacje z krakowskim „Przeglądem Lekarskim”, na łamach którego publikowali swoje prace i sprawozdania z posiedzeń jej członkowie, aż do momentu powołania przez środowisko poznańskie własnego specjalistycznego czasopisma - „Nowin Lekarskich” (1889). Założenie tego pisma wspierał sam Majer, będący już wówczas prezesem AU. Szczególnie intensywna działalność międzyzaborowa prowadził Wydział Lekarski PTPN w latach 1908-1911, zapraszając z wykładami medyków z innych zaborów i aktywnie uczestnicząc w zjazdach naukowych w Krakowie, Warszawie czy Lwowie. Partnerem naukowym Wydziału Lekarskiego PTPN było również Cesarskie Wileńskie Towarzystwo Lekarskie, o czym wspomina w swojej książce Ilgiewicz ${ }^{29}$. Warto tu przy okazji zaznaczyć, że właściwie we wszystkich ośrodkach na ziemiach polskich środowiska medyczne działały dosyć prężnie, zrzeszając się i dążąc do zacieśniania kontaktów między sobą. Wynikało to z konieczności śledzenia szybkiego rozwoju wiedzy medycznej, zwłaszcza od drugiej połowy XIX w., oraz specyfiki praktyki lekarskiej, która wymagała nieustannego kształcenia się i wymieniania doświadczeń z nią związanych. Wyjątkową aktywność lekarzy ułatwiała też ich wysoka pozycja społeczna i niebudząca podejrzeń władz zaborczych profesja.

Wracajac do współpracujących z PTPN instytucji. Jedną z pierwszych, która, obok TNK, podjęła starania w kierunku nawiązania więzi z PTPN, było emigracyjne Towarzystwo Historyczno-Literackie w Paryżu (dalej: THL). Już 7 III 1858 r. jego prezes, książę Adam Jerzy Czartoryski, w liście do Działyńskiego jako prezesa PTPN pisał: „sądzę, że obydwa towarzystwa powinny by w bliższe wejść ze soba stosunki, udzielając sobie nastręczenia rady i pomoce" ${ }^{30}$. Zachęcał, by komunikację między nimi utrzymać za pośrednictwem Jana Działyńskiego i Władysława Czartoryskiego, którzy byli jednocześnie członkami

${ }^{28}$ Tamże, s. 284.

${ }^{29}$ Zob. też H. Ilgiewicz, dz. cyt., s. 99.

${ }^{30}$ Cyt. za R. Marciniak, Zwiazki Poznańskiego Towarzystwa Przyjaciót Nauk..., s. 283. 
obydwu towarzystw ${ }^{31}$. Jak zareagował na te propozycje Działyński, przynajmniej na razie, nie wiemy. Według Wiesława Cabana, autora artykułu o kontaktach THL z PTPN, nie nawiązały jednak te organizacje bliższych relacji ${ }^{32}$. Złożyły się na to, zdaniem Cabana, dwa powody. Po pierwsze, THL od połowy XIX w. stawiało przede wszystkim na współpracę z TNK, a następnie z AU, pozostawiając nieco na marginesie PTPN. Po drugie, i samo PTPN, mając własną koncepcje prac nad utrzymaniem polskości w Poznańskiem, nie wykazywało zbyt dużego zainteresowania stosunkami z THL. Niezależnie od tego, w ciagu 50 lat działalności THL przewinęło się przez nie, zgodnie z obliczeniami Cabana, 28 osób z Poznańskiego, z których 13 było członkami dobroczyńcami, przekazującymi pieniądze na rzecz Towarzystwa i Biblioteki Polskiej w Paryżu. Sam Caban przyznaje, że trudno określić, czy była to mała, czy duża reprezentacja poznańskiego środowiska naukowego w THL. Być może pozwola to lepiej określić dalsze badania nad kontaktami PTPN z THL, które powinny być w przyszłości kontynuowane.

Inna, w pewnym sensie sassiedzką instytucja, z którą PTPN weszło $\mathrm{w}$ relacje naukowe, było powstałe w $1885 \mathrm{r}$. towarzystwo niemieckie o nazwie Historische Gesellschaft für die Provinz Posen. Wokół kontaktów między nimi narosły różne, nie zawsze zgodne z rzeczywistościa wyobrażenia, co omawia w osobnym artykule autorka niniejszego tek$s^{33}$. Początki współistnienia obu towarzystw nie należały do łatwych. Wprawdzie nowo założone Historische Gesellschaft deklarowało przyjazne nastawienie wobec Polaków i PTPN, ale przez polskie Towarzystwo przyjęte ono zostało z rezerwą i nieufnością. Sceptycznie odniosło się zwłaszcza PTPN do celów Historische Gesellschaft, które planowało m.in. badanie wpływów niemieckich w historii Poznańskiego. Do pierwszego poważnego konfliktu między obu towarzystwami doszło we wrześniu 1885 r. Gdy udało się go przezwyciężyć, zarząd Historische Gesellschaft wprowadził zasadę, by unikać w przyszłości kontrowersyjnych sformułowań i jakiejkolwiek polemiki ze strona polską. Uznał również za niewskazane eksponowanie drażliwego tematu walki żywiołu niemieckiego ze słowiańskim w przeszłości. Zasada ta, nawet jeśli nie wynikała z głębokich przekonań Niemców, to w swoim podstawowym

31 Tamże, s. 283.

${ }^{32}$ W. Caban, Kontakty Towarzystwa Historyczno-Literackiego w Paryżu z instytucjami naukowymi i kulturalnymi w Wielkopolsce $w$ XIX wieku, w: Poznańskie Towarzystwo Przyjaciót Nauk a towarzystwa naukowe...

${ }^{33}$ A. Hinc, Poznańskie Towarzystwo Przyjaciót Nauk a Historische Gesellschaft für die Provinz Posen (1885-1914), w: Poznańskie Towarzystwo Przyjaciót Nauk a towarzystwa naukowe... 
zrębie pozostała $\mathrm{w}$ mocy do $1914 \mathrm{r} \cdot{ }^{34}$ Podobna politykę prowadził też prawdopodobnie zarząd PTPN lub kierownictwo jego Wydziału Historyczno-Literackiego, z którym Historische Gesellschaft miało najwięcej kontaktów. Po wypracowaniu więc w obu towarzystwach pewnych reguł wzajemnego funkcjonowania, stosunki naukowe między nimi układały się poprawnie, choć niepozbawione były elementu rywalizacji czy ostrożności. Oba towarzystwa wymieniały regularnie swoje wydawnictwa i recenzowały wzajemnie swoje prace. Jako ciekawostkę można dodać, że Historische Gesellschaft ceniło szczególnie zbiory Muzeum im. Mielżyńskich, zgromadzone przy PTPN. W 1894 r. pojawił się nawet pomysł przejęcia całości lub części tych zbiorów przez działające z ramienia niemieckiego towarzystwa Muzeum Prowincji w Poznaniu. Podjęte w tym kierunku starania zakończyły się jednak niepowodzeniem, ponieważ zarząd PTPN odmówił przekazania zbiorów ${ }^{35}$. Problematyka kontaktów PTPN z Historische Gesellschaft kryje w sobie jeszcze niewątpliwie wiele mało znanych spraw i powiązań, których zgłębienie umożliwi lepsze zrozumienie stosunków między polską a niemiecka inteligencja w Poznańskiem.

Interesującym sposobem poszerzania kontaktów naukowych PTPN było powoływanie przez nie, od 1860 r., członków honorowych i korespondentów spoza Poznańskiego ${ }^{36}$. Zwykło się uważać w dotychczasowej literaturze przedmiotu, że przyczyniali się oni bardzo do podniesienia prestiżu i znaczenia Towarzystwa, stając się niemal od razu jego ambasadorami i protektorami ${ }^{37}$. Zweryfikował ten pogląd Stanisław Borowiak, przedstawiając w swoim artykule faktyczną rolę członków honorowych i korespondentów w życiu PTPN ${ }^{38}$. Jak podaje Borowiak, w okresie zaborów obie te godności nadało Towarzystwo

${ }^{34}$ Por. T. Serrier, Provinz Posen, Ostmark, Wielkopolska. Eine Grenzregion zwischen Deutschen und Polen 1848-1914, Marburg 2005, s. 146.

${ }^{35}$ Por. T.I. Grabski, Okoliczności powstania Muzeum Prowincji w Poznaniu, w: Stulecie otwarcia Muzeum im. Cesarza Fryderyka $w$ Poznaniu, red. W. Suchocki i T. Żuchowski, Poznań 2004, s. 17; G. Haupt, Begründung und erste Geschichte des Museums, „Historische Monatsblätter für die Provinz Posen” 5, 1904, nr 11, s. 166.

${ }^{36}$ Nie licząc mianowanego członkiem honorowym w 1857 r. biskupa chełmińskiego Jana Nepomucena Marwicza (von der Marwitza), który notabene nie przyją ofiarowanej mu godności.

${ }^{37}$ Np. R. Marciniak, Prezesi Poznańskiego Towarzystwa Przyjaciót Nauk. Ich myśl i dzieło, Poznań 2006, s. 15.

${ }^{38} \mathrm{~S}$. Borowiak, Członkowie honorowi $i$ członkowie korespondenci a kontakty międzydzielnicowe $i$ wspótpraca międzynarodowa Poznańskiego Towarzystwa Przyjaciót Nauk $w$ drugiej połowie XIX $i$ na poczatku XX wieku, w: Poznańskie Towarzystwo Przyjaciót Nauk a towarzystwa naukowe... 
263 osobom, z których zdecydowana większość nie podjęła z nim szerszej współpracy, polegającej głównie na publikowaniu w wydawnictwach PTPN własnych prac. Wśród uhonorowanych osób dominowali wyraźnie uczeni polscy z zaboru austriackiego i rosyjskiego. Do rzadkości należały przypadki mianowania na członka honorowego lub korespondenta PTPN badaczy z zagranicznych ośrodków naukowych. Było ich bowiem tylko 26 , prezentujących przy tym najczęściej polonofilskie poglądy. Można zatem uznać $\mathrm{w}$ oparciu o te dane, że zakres oddziaływania naukowego PTPN nie był zbyt szeroki i ograniczał się przede wszystkim do ziem polskich pod zaborami.

Generalnie trzeba zauważyć, że wpływy naukowe i cała działalność PTPN nie wykraczała specjalnie poza granice trzech zaborów. Polski ośrodek naukowy w Poznaniu w XIX w. i na początku XX w. był za słaby, by rozwinąć aktywność w skali międzynarodowej. Nawet w skali międzyzaborowej nie zawsze prezentował się on wystarczająco silnie. Powody takiej sytuacji były różne: brak uniwersytetu, niechęć władz zaborczych wobec samoorganizacji naukowej polskich elit, koncentracja Polaków często na sprawach narodowych oraz niewielka w sumie atrakcyjność PTPN dla zagranicznych ośrodków naukowych. Z perspektywy natomiast prowincji poznańskiej PTPN odegrało ogromna rolę $\mathrm{w}$ integrowaniu i aktywizowaniu lokalnego środowiska inteligencji polskiej. Zważywszy dodatkowo na mała jej liczebność, osiagnięcia naukowe i organizacyjne PTPN należy ocenić wysoko, także z punktu widzenia podtrzymywania przez nie więzi międzyzaborowych.

Nie powiodły się natomiast do końca próby włączenia w struktury i działalność PTPN Polaków z pozostałych obszarów zaboru pruskiego, czyli Prus Zachodnich ${ }^{39}$. Wprawdzie niektórzy przedstawiciele tamtejszej inteligencji polskiej byli członkami PTPN, ale nie stworzyli oni na swoim terenie jakiegoś silnego lobby czy oddziału poznańskiego Towarzystwa. Wręcz przeciwnie, wzmacniając się coraz bardziej pod względem narodowym i intelektualnym, dążyli z czasem do powołania własnego towarzystwa naukowego. Dyskusje na ten temat toczyły się głównie w Toruniu i zakończyły ostatecznie założeniem w $1875 \mathrm{r}$. samodzielnej organizacji polskiej pod nazwą Towarzystwo Naukowe w Toruniu (dalej: TNT) ${ }^{40}$. Podstawowym jego zadaniem było badanie przeszłości Pomorza Gdańskiego oraz zbieranie wszelkich odnoszacych się do niego materiałów. Sam pomysł zawiązania w Toruniu odrębnego

${ }^{39}$ Zob. J. Michalski, dz. cyt., s. 321.

${ }^{40}$ Genezę powstania Towarzystwa Naukowego w Toruniu omawia szczegółowo K. Wajda, W dobie zaboru pruskiego 1875-1918, w: Dzieje Towarzystwa Naukowego $w$ Toruniu 1875-1975, red. M. Biskup, t. 1, Toruń 1977, s. 13-32. 
towarzystwa naukowego przyjęto $\mathrm{w}$ środowisku poznańskim $\mathrm{z}$ duża dezaprobata. W kręgach PTPN uważano bowiem, że działanie takie osłabi inteligencję polską zaboru pruskiego, która powinna raczej konsolidować swoje wysiłki, a nie rozpraszać się na mniejsze, pojedynczo funkcjonujące ośrodki. W tej sytuacji, dość trudnej dla obu towarzystw, niezwykle interesująca kwestia byłoby bliższe rozpoznanie, jak układały się potem ich wzajemne relacje naukowe. Najszerzej pisał o tym dotychczas Kazimierz Wajda, wskazując, że nawiązywanie relacji TNT z PTPN szło opornie i obciążone było w pierwszym okresie działalności Towarzystwa toruńskiego krytycznym stosunkiem do niego środowiska poznańskiego. Żywiona przez oba towarzystwa wzajemna niechęć była jeszcze widoczna w $1882 \mathrm{r}$., kiedy na walnym zebraniu TNT odrzucono wniosek jego prezesa Stanisława Kujota o wejście w kontakt z PTPN i wymianę dubletów znajdujących się w bibliotekach obu towarzystw ${ }^{41}$. Dopiero pod koniec XIX w. relacje między PTPN a TNT uległy znacznej poprawie ${ }^{42}$. Ich dokładniejszy przebieg nie jest jednak dobrze znany i powinien zostać $\mathrm{w}$ przyszłości przebadany.

Postulat przeprowadzenia solidnych badań trzeba również zgłosić $\mathrm{w}$ odniesieniu do zupełnie zaniedbanej tematyki kontaktów PTPN i TNT z innymi, tym razem niemieckimi towarzystwami naukowymi działajacymi w Prusach Zachodnich. Sprawa ta wydaje się o tyle ciekawa, że w 2. połowie XIX w. obserwujemy na terenie Prus Zachodnich prawdziwy wysyp niemieckich towarzystw naukowych, przeważnie o profilu historycznym. Do najważniejszych z nich należały: powstałe w 1853 r. w Toruniu Coppernicus-Verein für Wissenschaft und Kunst; założone w 1872 r. Verein für die Geschichte der Provinz Preussen, które od 1878 r. działało pod zmienioną nazwa Verein für die Geschichte von Ost- und Westpreussen; utworzone w 1873 r. Elbinger Altertumsgesellschaft; ustanowione w 1876 Historischer Verein für den Regierungsbezirk Marienwerder oraz zawiązane w 1879 r. Verein für die Stadt und den Regierungsbezirk Danzig, przemianowane w następnym roku na Westpreußischer Geschichtsverein. Wszystkie one propagowały niemiecka wizję przeszłości Prus Zachodnich i służyły kształtowaniu na jego obszarze tożsamości niemieckiej. Pisała o tym obszernie Magdalena Niedzielska, ukazując wymienione wyżej towarzystwa na bardzo szerokim tle całego niemieckiego ruchu stowarzyszeniowego. Z książki tej autorki wynika, że kontakty z polskimi

${ }^{41}$ Tamże, s. 53.

${ }^{42}$ Zob. J. Serczyk, Polskie instytucje naukowe, w: Historia nauki polskiej, red. B. Suchodolski, t. 4: 1863-1918, red. Z. Skubała-Tokarska, Wrocław 1987, s. 543. 
instytucjami naukowymi, zwłaszcza z PTPN i TNT, utrzymywały przynajmniej dwa niemieckie towarzystwa: Coppernicus-Verein für Wissenschaft und Kunst i Historischer Verein für den Regierungsbezirk Marienwerder ${ }^{43}$. Wzajemna ich współpraca polegała przede wszystkim na wymianie własnych wydawnictw.

\section{Zabór austriacki}

Dwoma głównymi ośrodkami życia naukowego w zaborze austriackim był Lwów i - z przerwą na lata 1809-1846 (okres Księstwa Warszawskiego i Rzeczypospolitej Krakowskiej) - Kraków. Ogólne warunki dla rozwoju tych ośrodków i całego życia umysłowego w zaborze austriackim do lat 70. XIX w. były bardzo trudne. Władza austriacka skupiła się bowiem na maksymalnym wyzysku fiskalnym polskich ziem, w niewielkim stopniu dbajac o jakikolwiek ich wzrost. Podupadły szczególnie gospodarka i szkolnictwo. Zahamowane zostało poprzez system policyjny i ostra cenzurę życie kulturalne i naukowe.

$\mathrm{Na}$ tle tej wyjątkowo niekorzystnej sytuacji wyróżniał się zdecydowanie Kraków, który z uwagi na swoją bogatą tradycję uniwersytecką stanowił w zaborze austriackim pewną umysłową enklawę. Jak wiadomo, uniwersytet - zwany oficjalnie, po reformie przeprowadzonej jeszcze w czasach polskich przez Komisję Edukacji Narodowej, Szkoła Główną Koronna - mimo różnych trudności, łącznie z zagrożeniem zamknięcia, gdy Austriacy wkroczyli do Krakowa, przetrwał rozbiory. Nie uchronił się natomiast przed stopniowym zacieraniem jego polskiego charakteru oraz utratą znacznej części swojej autonomii i funkcji sprawowania nadzoru nad szkolnictwem średnim. Nadal mógł jednak kształcić młodzież polską i gromadzić wokół siebie uczonych. W latach 1809-1846 przywrócono uniwersytetowi polskie właściwości i starano się nadać mu rangę centralnej jednostki dla życia naukowego ${ }^{44}$.

Tej idei służyło założone w 1815 r. z inicjatywy rektora Walentego Litwińskiego Towarzystwo Naukowe ściśle powiązane z uczelnią. Jego członkami byli z urzędu profesorowie, a prezesem rektor. Za podstawowy cel Towarzystwa uznano podniesienie poziomu naukowego uniwersytetu i krzewienie oświaty w społeczeństwie polskim. W realizacji całego przedsięwzięcia Litwiński wzorował się na Warszawskim

${ }^{43}$ M. Niedzielska, Niemieckie towarzystwa naukowe $w$ Prusach Zachodnich w latach 1815-1920..., s. 85, 86, 115, 166, 171-172; taż, Niemieckie towarzystwa naukowe w Prusach Zachodnich - historia polityczna...

${ }^{44}$ Por. J. Michalski, dz. cyt., s. 123-127. 
Towarzystwie Przyjaciół Nauk, do którego zwracał się nawet o pomoc i wsparcie, ale bez specjalnego odzewu ${ }^{45}$. Początkowo Towarzystwo Naukowe nie spełniało swojego zadania, ponieważ działało dość niemrawo, odzwierciedlajac $\mathrm{w}$ dużej mierze kiepską kondycję naukowa uniwersytetu, zwanego od 1817 r. Uniwersytetem Jagiellońskim (dalej: UJ). Dopiero wybór na rektora uczelni Józefa Majera w 1848 r. wpłynął ożywczo zarówno na działalność Uniwersytetu, jak i Towarzystwa. Sprzyjała temu, przez krótki czas, ogólna sytuacja polityczna w zaborze austriackim, która dawała Polakom nadzieję na większe swobody narodowe. Na fali tych nastrojów pojawił się w Towarzystwie i na Uniwersytecie po raz pierwszy pomysł nadania tym instytucjom bardziej ogólnonarodowego charakteru. Widoczną oznaką takiego myślenia było powołanie przez Towarzystwo w latach 1848-1851 wielu nowych członków korespondentów, reprezentujących przede wszystkim zabór rosyjski i polskie środowisko emigracyjne ${ }^{46}$.

Tymczasem w 1853 r. władze austriackie zawiesiły działalność Towarzystwa, żądając od niego przedłożenia stosownego statutu do zatwierdzenia, odpowiadającego nowo wprowadzonej ustawie o stowarzyszeniach. Następnie trzy lata zwlekały z przyjęciem przedłożonego statutu, co nastapiło ostatecznie w 1856 r., po ciagłych naleganiach Polaków. Wprawdzie władze austriackie zgodziły się wówczas na reaktywowanie Towarzystwa, ale pod warunkiem, że będzie ono funkcjonować odtąd samodzielnie i zerwie dotychczasowe związki z Uniwersytetem. Symbolicznym potwierdzeniem rozdziału obu instytucji było przemianowanie Towarzystwa na Cesarsko-Królewskie Towarzystwo Naukowe Krakowskie ${ }^{47}$. Stosunkowo szybko okazało się, że narzucone przez władze oderwanie się Towarzystwa od zgermanizowanego już wtedy Uniwersytetu miało w sumie pozytywne skutki. Doprowadziło bowiem do odrębnego bytu Towarzystwa, które zaczęło gromadzić własne zbiory: biblioteczne, przyrodnicze i starożytności oraz wystarało się, głównie za sprawą swojego pierwszego prezesa, Franciszka Wężyka,

45 Tamże, s. 143.

${ }^{46}$ Tamże, s. 261-262.

${ }^{47}$ Dla ścisłości warto dodać, że Towarzystwo kilkakrotnie zmieniało swoją nazwę. Pierwotnie brzmiała ona: Towarzystwo Naukowe Uniwersytetu Krakowskiego. Następnie, gdy uczelnia w r. akad. 1817/1818 przyjęła nazwę Uniwersytet Jagielloński, miano Towarzystwa zmieniło się na: Towarzystwo Naukowe Krakowskie z Uniwersytetem Jagiellońskim połączone. Z kolei w statucie z 1848 r. występuje ono jako: Towarzystwo Naukowe Krakowskie. Wreszcie w 1856 r., po odłączeniu się od uniwersytetu, jego nazwa była następująca: Cesarsko-Królewskie Towarzystwo Naukowe Krakowskie. Zob. D. Rederowa, Z dziejów Towarzystwa Naukowego Krakowskiego..., s. 108. 
o właściwą dla siebie siedzibę. Wznowiło jednocześnie, zahamowaną wcześniej, działalność naukowa, unowocześniając się i urastając z czasem do rangi rzeczywistego stymulatora życia umysłowego w Krakowie. Poza Krakowem zaś próbowało nawiązać współpracę naukową z innymi polskimi instytucjami, takimi jak choćby: PTPN, Wileńska Komisja Archeologiczna, redakcja „Biblioteki Warszawskiej” czy Zakład im. Ossolińskich we Lwowie ${ }^{48}$. Nie ulega przy tym watpliwości, że największy rozkwit TNK przypadł na lata 60 . XIX w., do czego przyczyniła się coraz bardziej korzystna dla Polaków sytuacja polityczna w zaborze austriackim, który od 1860 r. wchodził stopniowo na drogę autonomii. Okoliczność ta była podwójnie ważna dla całego ośrodka krakowskiego. Po pierwsze, dawała mu możliwość rozwijania bez przeszkód polskiego nurtu badań, a po drugie, przyciagała spora grupę wybitnych uczonych. Wszystko to powodowało, że Kraków stawał się powoli wiodącym ośrodkiem naukowym na ziemiach polskich.

Swoistym przypieczętowaniem tak dużej roli tego ośrodka było przekształcenie w 1872 r. TNK w AU, czyli najwyższa formę państwowej instytucji naukowej na ziemiach polskich. Akademia jako następczyni Towarzystwa przejęła automatycznie jego majątek, zbiory i siedzibę. Pierwsi jej członkowie, w liczbie 12, wywodzili się także z szeregów Towarzystwa i byli z niego specjalnie do Akademii wybrani. Wszyscy oni rekrutowali się celowo z miejscowego środowiska uczonych i stanowili tzw. minimum członków krakowskich, na których spoczywał ciężar administrowania i zarządzania $\mathrm{AU}^{49}$. Ten podstawowy dwunastoosobowy trzon Akademii uzupełniono później o dalszych członków, reprezentujących naukę polską w trzech zaborach i na emigracji. Szczególnie starano się pozyskać do współpracy przedstawicieli życia umysłowego z zaboru rosyjskiego i pruskiego. Dazżono w ten sposób do ogólnopolskiego charakteru AU, co udało się w znacznej mierze osiagnąć. Świadczyły o tym nie tylko imponujace spisy członków AU, ale także podejmowane przez nią działania o możliwie szerokim zasięgu. Były nimi m.in. międzyzaborowe zjazdy naukowe, połączone często $\mathrm{z}$ obchodami rocznic ku czci wybitnych Polaków bądź samodzielne uroczystości rocznicowe upamiętniające ważne postaci lub wydarzenia $z$ historii Polski, na których wzorowano się w pozostałych dwóch zaborach. Ponadto opiniowała AU, właściwie od początku swojej egzystencji, różne projekty, wykraczające niekiedy poza obszar zaboru austriackiego, jak

${ }^{48}$ J. Michalski, dz. cyt., s. 266. Por. S. Brzozowski, Akademia Umiejętności, w: Historia nauki polskiej..., t. 4, cz. 1-2, s. 186-187.

${ }^{49}$ J. Hulewicz, dz. cyt., s. 33. 
np. długo ciagnąca się sprawa ustalenia ortografii polskiej. Największym jednak przedsięwzięciem AU, które sama sobie ona wytyczyła, było włączenie się w nurt mało dostępnej do tej pory nauki europejskiej poprzez nawiazzywanie kontaktów międzynarodowych oraz publikowanie wydawnictw $\mathrm{w}$ językach obcych ${ }^{50}$. W obu tych kierunkach działalności odniosła AU spore sukcesy, utrzymujac pod koniec XIX w. wymianę swoich wydawnictw z 373 instytucjami naukowymi zarówno z terenu monarchii habsburskiej, a więc austriackimi, czeskimi i węgierskimi, jak i spoza niej ${ }^{51}$. W Europie Zachodniej najistotniejszym dokonaniem Akademii było utworzenie Stacji Naukowej w Paryżu oraz próby założenia podobnej stacji w Rzymie ${ }^{52}$.

Liczne kontakty międzynarodowe rozwijała także AU za pośrednictwem profesorów i docentów UJ. Było to związane z akcją stypendialna, jaką uruchomiła Akademia dla pracowników Uniwersytetu, umożliwiająca im wyjazdy zagraniczne w celu kształcenia się i prowadzenia badań ${ }^{53}$. Pobyty profesorów i docentów UJ za granica owocowały niejednokrotnie nowymi kontaktami naukowymi, które przekazywali oni następnie $\mathrm{AU}^{54}$. Ta wyjątkowa współpraca między obu krakowskimi instytucjami, która możliwa była dopiero po wprowadzeniu w Galicji autonomii, ujawniła się również na innych płaszczyznach, np. AU wydawała swoje publikacje naukowe prawie wyłacznie w drukarni UJ ${ }^{55}$. Dobrze układająca się zatem współpraca obu tych czoło-

${ }^{50}$ D. Rederowa, Ze studiów nad kontaktami Akademii Umiejętności..., s. 191-256; taż, Formy wspótpracy Polskiej Akademii Umiejętności..., s. 77-131; taż, Polska Stacja Naukowa..., s. 43-150; K. Stachowska, Kontakty Polskiej Akademii Umiejętności..., s. 109-124; taż, Polish-Swedish Contacts..., s. 107-122; taż, Z działalności wydawniczej Polskiej Akademii Umiejętności - starania o upowszechnianie za granica polskiej myśli naukowej w latach 1873-1952, „Rocznik B. PAN K.” 19, 1973, s. 39-71.

${ }^{51}$ D. Rederowa, Formy wspótpracy Polskiej Akademii Umiejętności..., s. 88-89.

${ }^{52}$ Polska Stacja Naukowa w Rzymie mogła powstać dopiero po odzyskaniu przez Polskę niepodległości, w 1927 r. Zob. D. Rederowa, B. Jaczewski, W. Rolbiecki, dz. cyt., s. $10-11$.

${ }^{53}$ Akcja stypendialna AU obejmowała także kadrę naukową uniwersytetu lwowskiego. Więcej na ten temat pisze M.J. Nedza, Polityka stypendialna Akademii Umiejętności w latach 1878-1920. Fundacje Gatęzowskiego, Pileckiego i Ostawskiego, Wrocław 1978. Zob. tė̇ J. Dużyk, Znaczenie Fundacji im. Śniadeckich dla rozwoju polskich badań naukowych w latach 1879-1912, „Rocznik B. PAN K.” 19, 1973, s. 102-133.

${ }^{54}$ J. Hulewicz, dz. cyt., s. 163.

${ }^{55}$ K. Stachowska, Akademia Umiejętności a Drukarnia Uniwersytetu Jagiellońskiego w latach 1873-1952, w: Studia z dziejów Drukarni Uniwersytetu Jagiellońskiego 1783-1974, red. L. Hajdukiewicz i J. Hulewicz, Kraków 1974, s. 151-168. Por. też S. Brzozowski, Uniwersytet Jagielloński, w: Historia nauki polskiej..., t. 4, cz. 1-2, s. $72-73$. 
wych instytucji naukowych w Krakowie przyczyniła się niewątpliwie do wzrostu ich znaczenia i stworzenia w tym mieście pierwszorzędnego ośrodka polskiego, który promieniował aż do wybuchu I wojny światowej na pozostałe zabory. Wzajemne oddziaływanie na siebie UJ i AU nie zostało jednak jeszcze $\mathrm{w}$ pełni zbadane. Nie dysponujemy dotąd żadnym szczegółowym opracowaniem tego tematu, a w monografiach ogólnych poświęconych obu instytucjom porusza się go raczej zdawkowo ${ }^{56}$. W konsekwencji ciagle niewiele wiemy, czy UJ i AU miały podobne kontakty naukowe, na ile potrafily je wykorzystać, w jakim stopniu kontakty te wpływały na inicjowanie lub intensyfikowanie badań naukowych oraz jaka rolę odgrywali uczeni związani z obu instytucjami? Aby odpowiedzieć na te pytania, należy w przyszłości przeprowadzić, możliwie szeroko zakrojone, badania porównawcze AU z UJ. Warto też przyjrzeć się bliżej mało znanym, kontaktom naukowym AU z archiwami galicyjskim, głównie krakowskimi i lwowskimi, które, zgodnie z zamiarem Akademii miały stać się miejscem pracy dla przedstawicieli świata umysłowego ${ }^{57}$.

Słabo rozpoznaną kwestią są również stosunki łączące AU i UJ z towarzystwami naukowymi powstałymi w Krakowie w dobie autonomii. Chodzi tu przede wszystkim o specjalistyczne towarzystwa naukowe, które odzwierciedlały szybki rozwój niektórych dziedzin wiedzy oraz dążenia integracyjne reprezentujących je środowisk naukowych lub grup zawodowych. Po $1866 \mathrm{r}$. towarzystw takich utworzono w Krakowie około 30. Do najprężniejszych z nich należały z całą pewnościa towarzystwa lekarskie, szczególnie aktywne we wszystkich trzech zaborach, o czym była już wcześniej mowa. Jednym z najbardziej

${ }^{56}$ S. Kutrzeba, dz. cyt., s. 41; J. Hulewicz, dz. cyt., s. 51-53, 85-86, 95. Poszczególne aspekty współpracy AU z UJ omówili: L. Kalinowski, Dzieje i dorobek naukowy Komisji Historii Sztuki Akademii Umiejętności i Polskiej Akademii Umiejętności 1873-1952 oraz powstanie Katedry Historii Sztuki Uniwersytetu Jagiellońskiego 1882, w: Dzieje historii sztuki w Polsce. Ksztattowanie się instytucji naukowych w XIX i XX wieku, red. A.S. Labuda przy współpr. K. Zawiasa-Staniszewska, Poznań 1996, s. 22-57; K. Stachowska, Akademia Umiejętności..., s. 151-168.

${ }^{57}$ Zob. B. Schnaydrowa, Opieka Akademii Umiejętności nad archiwami galicyjskimi, „Rocznik B. PAN K.” 18, 1972, s. 21-36. Por. też S. Ciara, Archiwa a uniwersytety $w$ Krakowie i Lwowie w latach 1877/78-1918, Warszawa 2002. Akademia Umiejętności współpracowała również z innymi instytucjami kultury. Pisali o tym: J. Staszel, Fundacja im. Mikołaja Kopernika w Krakowie i jej zwiazki z Akademia Umiejętności, „Rocznik B. PAN K.” 19, 1973, s. 73-99; tenże, Zwiazki Muzeum Raperswilskiego $z$ Akademia Umiejętności $w$ świetle korespondencji Wtadystawa Platera, „Rocznik B. PAN K.” 21, 1975, s. 133-165; J. Nowak, Wspótpraca Akademii Umiejętności i Zarzadu Zbiorów Czartoryskich w Krakowie w latach 1874-1894, „Rocznik B. PAN K.” 36, 1991, s. 61-74. 
znaczących tego typu zrzeszeń było Towarzystwo Lekarskie Krakowskie, założone w 1866 r. przez Aleksandra Kremera. Prezesami tej organizacji do 1918 r. byli przeważnie profesorowie UJ. Zanim Towarzystwo wybudowało własny gmach, obradowało w siedzibie AU, co pokazuje już pewne powiązania między tymi instytucjami. Wśród różnych przejawów działalności Towarzystwa na uwagę zasługują zwłaszcza zainicjowane przez nie ponadzaborowe zjazdy lekarzy i przyrodników polskich, odbywające się od 1869 r. ${ }^{58}$ Umacniały one i rozwijały środowiska lekarskie, tworzace coraz bardziej wyspecjalizowane zrzeszenia. Widać to bardzo dobrze na przykładzie Krakowa, gdzie zawiązały się m.in.: Towarzystwo Chirurgów Polskich (1889), Towarzystwo Ginekologiczne Krakowskie (1889), Towarzystwo Opieki Zdrowia (1889), Krakowskie Towarzystwo Dermatologiczne (1901) czy Towarzystwo Stomatologów Polskich (1907). Kontakty między nimi i odpowiadającymi im instytucjami naukowymi nie zajmowały do tej pory historyków. Nie interesowały ich także specjalnie kontakty pozostałych krakowskich towarzystw naukowych, takich jak choćby: Towarzystwa dla Popierania Polskiej Nauki Rolnictwa (1902) czy Towarzystwa Miłośników Historii i Zabytków Krakowa (1896) ${ }^{59}$.

Inną bardzo dotkliwa luką badawczą w dotychczasowej literaturze przedmiotu sa relacje krakowskiego środowiska naukowego z lwowskim - drugim co do wielkości i ważności w zaborze austriackim. Jedyną większą publikacją dotycząca tej problematyki jest, wydana zreszta niedawno, praca Marioli Hoszowskiej ${ }^{60}$. Trzeba jednak od razu zaznaczyć, że autorka odnosi się w niej do jednego tylko aspektu całej problematyki, a mianowicie kontaktów lwowskiego historyka Ludwika Finkla z AU. Ten sam kierunek badań obrali wcześniej Rita Majkowska, która opisała związki literata i redaktora lwowskiego Władysława Łozińskiego z AU, oraz Józef Dużyk, który przeanalizował kontakty naukowe kolejnego historyka lwowskiego, Wojciecha Kętrzyńskiego, z Krakowem ${ }^{61}$. Pokrewną temu kwestię poruszył z kolei w swoim artykule Witalij Telwak, badacz ukraiński, który omówił organizację

${ }^{58}$ Więcej na temat tych zjazdów pisze J. Cabaj, „Walczyć nauka za sprawę Ojczyzny”. Zjazdy ponadzaborowe polskich środowisk naukowych i zawodowych jako czynnik integracji narodowej (1869-1914), Siedlce 2007.

${ }^{59}$ Zob. S. Brzozowski, Towarzystwa naukowe $w$ Krakowie, w: Historia nauki polskiej..., t. 4, cz. 1-2, s. 227-240.

${ }^{60}$ M. Hoszowska, Ludwik Finkel i Akademia Umiejętności. Z dziejów wspótpracy naukowej Lwowa i Krakowa na przełomie XIX i XX wieku, Rzeszów 2011.

${ }^{61}$ R. Majkowska, Zwiazki Władystawa Eozińskiego z Akademia Umiejętności $w$ Krakowie, „Rocznik B. PAN K.” 20, 1974, s. 125-140; J. Dużyk, Wojciecha Kętrzyńskiego zwiazki naukowe z Krakowem, „Rocznik B. PAN K.” 14, 1968, s. 263-287. 
i działalność Grona Lwowskiego Komisji Historycznej AU, będącego oddziałem analogicznej Komisji AU w Krakowie ${ }^{62}$. Te pojedyncze w sumie opracowania, choć rzucaja pewne światło na stosunki naukowe Krakowa i Lwowa, sa zupełnie niewystarczające i bardzo wycinkowe. Ograniczaja się w zasadzie do relacji uczonych lwowskich z krakowska AU. Tymczasem kontakty naukowe Krakowa i Lwowa były znacznie bogatsze i zachodziły między różnymi instytucjami szeroko rozumianej kultury oraz środowiskami umysłowymi obu miast. Ukazuje to bardzo dobrze artykuł Iryny Macewko, również pochodzacej z Ukrainy badaczki, która przedstawiła stosunki powstałego w 1901 r. krakowskiego Klubu Słowiańskiego, skupiającego polskich intelektualistów $\mathrm{z}$ ukraińskim środowiskiem historycznym Lwowa ${ }^{63}$. W tym kierunku powinny pójść właśnie przyszłe badania, akcentujące zwłaszcza relacje zachodzace między najważniejszymi instytucjami naukowymi obu miast.

We Lwowie główną taką instytucją był uniwersytet, założony w 1784 r. przez cesarza Józefa II w miejsce dawnej Akademii Jezuickiej. Sam cesarz nadał mu nazwę Uniwersytet Józefiński. Początkowo nie stanowił on jakiegoś większego ośrodka naukowego, ponieważ jego struktura i charakter nastawione były na kształcenie urzędników, księży i lekarzy, a więc przedstawicieli praktycznych i potrzebnych wówczas profesji. Podstawowym językiem wykładowym była łacina, a językami pomocniczymi polski i ruski. Wśród profesorów przeważali Niemcy lub zniemczeni reprezentanci innych narodowości monarchii habsburskiej. W 1805 r., z uwagi na włączenie do zaboru austriackiego tzw. Galicji Zachodniej z Krakowem, władze wiedeńskie zdecydowały o połączeniu uniwersytetu krakowskiego z lwowskim i przeniesieniu tego ostatniego do Krakowa. Nie chciały bowiem utrzymywać dwóch uniwersytetów na ziemiach polskich. We Lwowie utworzyły tylko Liceum Lwowskie, które było instytucją pośrednią między szkołą średnią a uniwersytetem ${ }^{64}$.

${ }^{62}$ W. Telwak, Organizacja i działalność Lwowskiego Grona Komisji Historycznej Akademii Umiejętności, „Rocznik Biblioteki PAU i PAN w Krakowie” 50, 2005, s. 13-26.

${ }^{63}$ I. Мацевко (I. Macewko), Стосунки краківського Слов'янського клубу з українським історичним середовищел Львова [Stosunki krakowskiego Klubu Słowiańskiego z ukraińskim środowiskiem historycznym Lwowa], w: Wielokulturowe środowisko historyczne Lwowa w XIX i XX w., red. J. Maternicki, L. Zaszkilniak, t. 5, Rzeszów 2007, s. 306-316.

${ }^{64}$ J. Michalski, dz. cyt., s. 145-146. Według Petera Lundgreena uniwersytet lwowski zdegradowany został do rangi liceum (1805-1817). Zob. P. Lundgreen, Uniwersytet Lwowski $i$ jego historycy (1784-1914): perspektywa porównawcza niemieckiego $i$ austriackiego rozwoju, w: Wielokulturowe środowisko historyczne Lwowa w XIX i XX w., red. J. Maternicki, t. 1, Rzeszów 2004, s. 105. Por. L. Finkel, S. Starzyński, Historya Uniwersytetu Lwowskiego, Lwów 1894, cz. 1, s. 153, 155-175. 
Sytuacja zmieniła się ponownie w 1817 r., kiedy po kongresie wiedeńskim, który wyłączył Kraków spod jurysdykcji Austrii, jej cesarz Franciszek I reaktywował uniwersytet we Lwowie, przekształcajac w tym celu Liceum. Powołany jednak przez niego Uniwersytet Franciszkański, bo tak brzmiała oficjalna jego nazwa, był pod względem możliwości edukacyjnych znacznie skromniejszy od Uniwersytetu Józefińskiego ${ }^{65}$. Został natomiast mocno zniemczony i poddany ścisłej kontroli miejscowych władz administracyjnych oraz ostrej cenzurze ${ }^{66}$. Nie prezentował przy tym zbyt wysokiego poziomu naukowego. Być może dlatego niepowodzeniem zakończyły się starania założenia w owych latach towarzystwa naukowego skupiajacego niemieckie kadry uniwersyteckie, z których wyszła ta idea, i polskich uczonych ${ }^{67}$. Gorącym orędownikiem takiego towarzystwa był m.in. Józef Maksymilian Ossoliński, twórca polskiej fundacji narodowej, omówionej poniżej68.

Zwrot w historii Uniwersytetu nastapił w 1848 r., w którym na fali ogólnych wydarzeń politycznych władze austriackie wydały zezwolenie na prowadzenie wykładów w języku polskim (22 IV). Wprawdzie przetrwały one wtedy zaledwie $40 \mathrm{dni}$, ale wywołały uaktywnienie się tamtejszych elit polskich związanych z uczelnią. Od tamtego też czasu rozpoczał się trudny i długotrwały proces polonizacji Uniwersytetu, który zakończył się zasadniczo w 1871 r. wydaniem dekretu cesarskiego, znoszącego język niemiecki jako wykładowy na Wydziale Prawnym i Wydziale Filozoficznym, a wprowadzajacego w zamian języki polski i ukraiński69. Dekret ten skierował Uniwersytet Franciszkański na zupełnie nowe tory. Spowodował, że rozwijały się na nim odtąd nauki

${ }^{65}$ Uniwersytet Józefiński składał się z czterech wydziałów: Filozoficznego, Prawnego, Medycznego i Teologicznego, podczas gdy Uniwersytet Franciszkański tylko z trzech (bez Wydziału Medycznego). Zob. J. Michalski, dz. cyt., s. 145-148; L. Finkel, S. Starzyński, dz. cyt., cz. 1, s. 213.

${ }^{66}$ Język niemiecki jako wykładowy wprowadzono w 1817 r. najpierw dla niektórych tylko przedmiotów, a następnie w 1824 dla wszystkich przedmiotów. Zob. P. Lundgreen, Uniwersytet Lwowski..., s. 105.

${ }^{67}$ J. Michalski, dz. cyt., s. 149. O idei założenia polsko-niemieckiego towarzystwa naukowego we Lwowie wspomina także T. Modelski, Ossolineum i Czeskie Muzeum Narodowe. (Pierwsze zwiazki i zawiazki), „Rocznik Zakładu Narodowego im. Ossolińskich" 4, 1953, s. 82 [276].

${ }^{68}$ Rolę J.M. Ossolińskiego w staraniach o założenie polsko-niemieckiego towarzystwa naukowego we Lwowie po 1817 r. omawia szerzej W. Jabłońska, Józef Maksymilian Ossoliński. Szkic biograficzny, Wrocław 1967, s. 63-64.

${ }^{69}$ Ostatecznie proces polonizacji uniwersytetu zakończył się dopiero w 1879 r., po zniesieniu języka niemieckiego jako urzędowego uczelni, za pomocą którego jej przedstawiciele komunikowali się dotąd ze wszystkimi władzami. Zob. S. Brzozowski, Uniwersytet Lwowski, w: Historia nauki polskiej..., t. 4, cz. 1-2, s. 243-244. 
polska i ukraińska, które dla kształtowania się we Lwowie życia umysłowego Polaków i Ukraińców miały ogromne znaczenie. Zaangażowanie ich elit w rozkwit Uniwersytetu sprawiło, że w ciagu najbliższych lat urósł on do rangi pierwszorzędnego ośrodka naukowego na ziemiach polskich, równorzędnego i partnerskiego w stosunku do Krakowa.

Druga instytucja, wokół której koncentrowało się życie naukowe Lwowa, była fundacja Józefa Maksymiliana Ossolińskiego - pisarza, historyka i bibliofila, osiadłego w 1790 r. w Wiedniu. Fundacja jego imienia powstała w $1817 \mathrm{r}$. w celu założenia we Lwowie biblioteki, na która składać się miały pokaźne zbiory biblioteczne Ossolińskiego oraz kolekcje grafiki, malarstwa i numizmatów. Zgodnie z zapisami fundacji Ossoliński zapewnił podstawy finansowe biblioteki, która otrzymała nazwę Zakład Narodowy imienia Ossolińskich (Ossolineum). W 1823 r. powiększyła ona jeszcze swoje zasoby o zbiory księcia Henryka Lubomirskiego, które ulokowano przy bibliotece jako tzw. Muzeum im. Lubomirskich. W związku z tym, że organizacja Zakładu zajęła Ossolińskiemu wiele lat (musiał zakupić i przystosować do niego budynki), przewiezienie zbiorów z Wiednia do Lwowa nastapiło dopiero w $1827 \mathrm{r}$., czyli rok po śmierci fundatora (17 III 1826 r.). Wtedy właściwie zaczęła się faktyczna działalność Zakładu, która nie ograniczała się tylko do zarządzania księgozbiorem, ale wiązała się także z określonym przez Ossolińskiego szerokim programem naukowo-wydawniczym, wyrażajacym się przede wszystkim w obowiązku wydawania czasopisma literackiego oraz założenia przy nim towarzystwa naukowego i własnej drukarni $^{70}$. Precyzyjnie sformułowane wytyczne Ossolińskiego dotyczące funkcjonowania Zakładu wprowadzali stopniowo w życie kolejni jego dyrektorzy.

Pierwszy z nich, ksiądz Franciszek Siarczyński, już w 1828 r. zapoczątkował wydawanie periodyku Zakładu pt. „Czasopism Naukowy Księgozbioru Publicznego im. Ossolińskich”. Wzorem dla tego periodyku, jedynego zresztą wówczas naukowego w Galicji, był czeski „Č́apis Společnosti Vlastenského Museum v Čechach” wydawany przez Muzeum Narodowe w Pradze ${ }^{71}$. Z instytucja ta, istniejąca od 1818 r., utrzymywał kontakty zarówno Ossoliński, jak i Siarczyński, który zainspirował się działajacym przy niej towarzystwem naukowym. Jeszcze w 1828 r. podją on starania zmierzajace do powołania podobnego towa-

${ }^{70}$ W. Jabłońska, dz. cyt., s. 100-108.

${ }^{71}$ Przekonuje o tym w swoim artykule T. Modelski (dz. cyt., s. 1-98 [195-292]), który opisuje szczegółowo pierwsze związki Zakładu Narodowego im. Ossolińskich we Lwowie z Muzeum Narodowym w Pradze. Por. J. Trzynadlowski, Zaktad Narodowy imienia Ossolińskich 1817-1967. Zarys dziejów, Wrocław 1967, s. 46-48. 
rzystwa połączonego z Zakładem. Zabiegi Siarczyńskiego z tym związane nie przyniosły jednak oczekiwanego rezultatu, ponieważ władze austriackie odwlekały wydanie zgody na zaplanowane w duchu polskim towarzystwo. Dodatkowo w 1829 r. zmarł Siarczyński, co spowodowało, przynajmniej chwilowe, zawieszenie sprawy.

Program naukowo-wydawniczy Ossolińskiego realizował też z dużym zapałem następca Siarczyńskiego na stanowisku dyrektora Zakładu, Konstanty Słotwiński. W 1832 r. udało mu się otworzyć czytelnię Zakładu, niezwykle ważne miejsce dla lwowskich uczonych, a w 1833 drukarnię i litografię, w której wydawał książki polskie, m.in. zakazane przez władze austriackie. Wdrożył również starania o założenie towarzystwa naukowego przy Zakładzie, które wprawdzie utworzył w 1832 r., ale bez urzędowego zatwierdzenia. Zyskał dzięki temu dla Ossolineum współpracowników, którzy zasilali swoimi pracami czasopismo Zakładu. Do towarzystwa należało około 70 osób reprezentujących środowiska naukowe i literackie z trzech zaborów oraz z zagranicy. Ich spotkania odbywały się $\mathrm{w}$ gmachu Zakładu. Całe przedsięwzięcie Słotwińskiego nie zostało jednak nigdy sformalizowane ${ }^{72}$. Wszelkie szanse na to zaprzepaściło ostatecznie policyjne odkrycie drukowanych przez niego w konspiracji pism rewolucyjnych. Konsekwencją tego było zamknięcie de facto na pewien czas Zakładu ${ }^{73}$.

Ponowne otwarcie Ossolineum i przywrócenie jego aktywności nastapiło w latach 40. XIX w., za dyrektury Adama Kłodzińskiego. W 1841 r. wznowił on bowiem wydawanie periodyku Zakładu, w 1847 uzyskał zezwolenie władz na uruchomienie drukarni, a w 1848 - czytelni. Jednocześnie w 1848 r. powrócił Kłodziński wraz z grupa kilkunastu innych przedstawicieli życia umysłowego ówczesnego Lwowa do idei zawiązania polskiego towarzystwa naukowego przy Ossolineum, ale i tym razem, z powodu napięć politycznych, nie doszło do jej urzeczywistnienia $^{74}$. Jak się później okazało, mimo wysiłków różnych osób towarzystwo naukowe przy Zakładzie oficjalnie nigdy nie powstało.

Samo zaś Ossolineum odegrało ogromną rolę w organizacji życia naukowego we Lwowie. Przyczyniło się zwłaszcza do ożywienia polskich elit lwowskich, które przed 1830 r. nie wykazywały specjalnej działalności i nie miały żadnego oparcia instytucjonalnego. Dopiero za sprawa Ossolineum, które nie sprowadzało się tylko do biblioteki i muzeum,

${ }^{72}$ Więcej na temat towarzystwa naukowego założonego przez Słotwińskiego przy Ossolineum pisze H. Łapiński, U poczatków działalności wydawniczej Ossolineum 1817-1834, Wrocław 1973, s. 53-55, 117-118.

${ }^{73}$ J. Trzynadlowski, dz. cyt., s. 50-58.

${ }^{74}$ J. Michalski, dz. cyt., s. 289-290. 
zaczęły one tworzyć powoli we Lwowie silny ośrodek naukowy, konkurujący i nadrabiający zaległości w stosunku do Krakowa. W murach Ossolineum, oprócz biblioteki i muzeum znajdowało się także dobrze prosperujace i coraz bardziej rozpoznawalne na ziemiach polskich wydawnictwo naukowe. Wszystko to sprawiło, że w okresie autonomii galicyjskiej, po polonizacji uniwersytetów krakowskiego i lwowskiego, Zakład Narodowy im. Ossolińskich był jedną z najbardziej liczących się polskich instytucji naukowych, porównywanych do Biblioteki Jagiellońskiej czy Muzeum Polskiego w Rapperswilu ${ }^{75}$.

W kontekście tak wysokiej pozycji Ossolineum w nauce polskiej XIX w. trzeba podkreślić, że nie doczekało się ono do tej pory opracowania kontaktów, jakie łączyły je z innymi instytucjami naukowymi na ziemiach polskich i poza nimi. Dysponujemy na ten temat zaledwie kilkoma pracami, z których najbardziej wartościowa jest niewątpliwie rozprawa Teofila Modelskiego dotycząca pierwszych związków Ossolineum z Muzeum Narodowym w Pradze ${ }^{76}$. Brak szerszych badań w tym zakresie wynika prawdopodobnie $\mathrm{z}$ faktu niedocenienia ich znaczenia oraz stąd, że generalnie słabo opisane są dotąd dzieje Zakładu. Do sformułowanego zatem jeszcze w latach 60. XX w. przez Antoniego Knota postulatu napisania pełnej monografii historycznej Zakładu należy dodać wniosek przeanalizowania również jego kontaktów naukowych z partnerskimi placówkami ${ }^{77}$. W pierwszej kolejności prześledzić warto relacje, w jakie wchodziło Ossolineum z Uniwersytetem Franciszkańskim.

${ }^{75} \mathrm{O}$ roli Ossolineum podczas dyrektury Kłodzińskiego pisze I. Lewandowska-Jaraczewska, Ossolineum w życiu spotecznym i kulturalnym Galicji w latach 1839-1849, „Ze Skarbca Kultury” 33, 1980, s. 165-192.

${ }^{76}$ T. Modelski, dz. cyt., s. 1-98 [195-292]. Tej samej problematyki dotycza trzy kolejne artykuły: K. Krejči, Ossolineum i życie kulturalne Czechów i Stowaków, w: Zakład imienia Ossolińskich 1827-1956. W dziesięciolecie działalności we Wroctawiu, Wrocław 1956, s. 135-137; T. Żabski, Ossolineum w listach Adama Junoszy Rościszewskiego do Vaclava Hanki (1829-1844), „Ze Skarbca Kultury” 19, 1967, s. 145-199; A. Knot, Zwiazki J. M. Ossolińskiego z naukq czeska, „Roczniki Biblioteczne” 11, 1967, z. 3/4, s. 257-312. Wątek kontaktów Ossolineum z innymi instytucjami naukowymi pojawia się też w książce H. Łapińskiego, dz. cyt., s. 56, 101-102, oraz w artykule R. Majkowskiej, Wtadysław Eozinsski w Ossolineum (1870-1872), „Rocznik Zakładu Narodowego im. Ossolińskich” 8, 1973, s. 149-151.

${ }^{77}$ Postulat opracowania pełnej monografii historycznej Ossolineum sformułował A. Knot w 1967 r. przy okazji obchodów 150-lecia tej instytucji. Zob. A. Knot, Dzieje Zakładu Narodowego im. Ossolińskich. Stan badań i postulaty, „Rocznik Zakładu Narodowego im. Ossolińskich" 6, 1970, s. 61-72. O braku należytego opracowania roli Ossolineum w dziejach historiografii polskiej wspomina też J. Maternicki, Polskie badania nad lwowskim środowiskiem historycznym $w$ XIX $i X X w$., w: Wielokulturowe środowisko historyczne..., t. 1, s. 44. 
Wiadomo na przykład, że profesorowie Uniwersytetu wchodzili w skład komisji oceniajacej prace kandydatów na kustoszy Ossolineum oraz byli jego konsultantami bibliotecznymi ${ }^{78}$. Szczególny rodzaj więzi mógł też wytworzyć się między tymi instytucjami poprzez stypendystów Ossolineum, rekrutujących się właśnie z Uniwersytetu Franciszkańskiego ${ }^{79}$.

Osobna kwestią zupełnie pomijaną dotąd w literaturze, sa stosunki Ossolineum z różnymi towarzystwami naukowymi. W kilku przypadkach opisane zostały jedynie kontakty Zakładu z poszczególnymi uczonymi polskimi, związanymi wprawdzie niekiedy z konkretnymi towarzystwami, ale jednak rozwijającymi relacje z ossolińczykami indywidualnie $^{80}$. Szersze badania warto rozpocząć od naświetlenia powiązań Zakładu z najbliższymi mu towarzystwami lwowskimi.

W okresie autonomii towarzystwa naukowe we Lwowie powstawały nieco później niż w Krakowie. Pierwszym z nich było Polskie Towarzystwo Przyrodników im. Kopernika, założone w 1875 r. z inicjatywy Bronisława Radziszewskiego i Feliksa Kreutza dla uczczenia 400-lecia urodzin Mikołaja Kopernika, które obchodzono w 1873 r. Towarzystwo stawiało sobie za cel badanie przyrody ojczystej, integrowanie przyrodników polskich pracujacych w trzech zaborach i na emigracji, stymulowanie wymiany ich doświadczeń naukowych oraz popularyzację wiedzy przyrodniczej. Od początku zakładało ono współpracę z Komisją Fizjograficzną AU jako jedną z najważniejszych instytucji naukowych w Galicji. Jak układała się ta współpraca, trudno na razie powiedzieć, ponieważ nie była ona dotąd przedmiotem dociekań historyków. Dalszą współpracę naukową nawiązało Towarzystwo Przyrodników przy okazji akcji, której patronowało - inwentaryzacji zabytkowych obiektów przyrody na terenie Galicji. Kontaktowało się wówczas z różnymi analogicznymi organizacjami polskimi i niemieckimi, m.in. z Polskim Towarzystwem Krajoznawczym z Warszawy. Niezależnie od tej akcji współdziałało też Towarzystwo z Uniwersytetem Franciszkańskim, Towarzystwem Szkoły Ludowej, Towarzystwem Oświaty Ludowej, Towarzystwem Kursów Uniwersyteckich dla Kobiet, PTPN i TNW. Przed I wojna światowa finansowo wspierała je ponadto warszawska Kasa im. Mianow-

${ }^{78}$ H. Łapiński, dz. cyt., s. 56.

${ }^{79}$ Zob. I. Król, Stypendyści ossolińscy w latach 1830-1914, „Czasopismo Zakładu Narodowego im. Ossolińskich” 9, 1998, s. 137-142.

${ }^{80}$ E. Triller, Zwiazki Stanisława Konstantego Pietruskiego z Zaktadem Narodowym im. Ossolińskich, „Ze Skarbca Kultury” 33, 1980, s. 193-227; taż, Zwiazki Karola Beyera z Zaktadem Narodowym im. Ossolinskich, „Ze Skarbca Kultury” 36, 1982, s. 161-204; W. Szalkiewicz, Z kontaktów naukowych Wiktora Kalinowskiego z Augustem Bielowskim w latach 1857-1861, „Ze Skarbca Kultury” 47, 1988, s. 117-142. 
skiego. Towarzystwo wydawało również własny periodyk „Kosmos”, który przesyłało do różnych ośrodków ${ }^{81}$. W sumie prowadziło niemała działalność naukowa. Ustanowiło nawet własne oddziały w Krakowie i Stanisławowie oraz stacje biologiczne w Oparach koło Drohobycza i w Drozdowicach koło Gródka Jagiellońskiego. Posiadało najstarszą na ziemiach polskich specjalistyczną bibliotekę przyrodnicza. O jego kontaktach naukowych wiemy już dość sporo, ale zapewne nie wszystko.

Gorzej pod tym względem wygląda stan badań nad lwowskim Towarzystwem Historycznym (dalej: TH), utworzonym w 1886 r. z inspiracji pracowników Uniwersytetu Franciszkańskiego, głównie Ludwika Finkla, Fryderyka Papéego i Ksawerego Liskego. Celem Towarzystwa było rozwijanie nauk historycznych, nawiązanie łączności z podobnymi instytucjami za zagranica oraz wydawanie specjalistycznego czasopisma, informującego o polskim i obcym piśmiennictwie historycznym ${ }^{82}$. Do największych osiagnięć Towarzystwa zaliczyć trzeba powołanie w 1887 r. właśnie owego czasopisma - „Kwartalnika Historycznego”, oraz zorganizowanie przed I wojna światowa trzech ważnych dla polskiej historiografii zjazdów naukowych. Wśród członków Towarzystwa dominowali zdecydowanie historycy lwowscy, choć nie brakowało w nim również przedstawicieli dwóch pozostałych zaborów, zwłaszcza rosyjskiego. Oprócz Polaków należało do Towarzystwa kilkunastu historyków ukraińskich oraz pojedynczy Niemcy i Czesi ${ }^{83}$. Mimo wyraźnego nastawienia Towarzystwa na zawiazywanie i podtrzymywanie kontaktów międzyzaborowych i zagranicznych w ramach środowisk historycznych, jego związki z innymi, odpowiadającymi mu instytucjami czy poszczególnymi uczonymi nie zostały jeszcze wystarczająco omówione. Niewątpliwie najważniejszym partnerem Towarzystwa był Uniwersytet Franciszkański oraz, jak można przypuszczać, Ossolineum i archiwa lwowskie ${ }^{84}$. Ciagle nie znamy jednak szczegółów współpracy

${ }^{81}$ K. Maślankiewicz, Z. Wójcik, 1875-1975 - 100 lat Polskiego Towarzystwa Przyrodników im. Kopernika, w: Polskie Towarzystwo Przyrodników im. Kopernika 1875-1975, red. K. Maślankiewicz, Warszawa 1981, s. 17-49. Por. S. Brzozowski, Towarzystwa naukowe we Lwowie, w: Historia nauki polskiej..., t. 4, cz. 1-2, s. 349-350.

${ }^{82}$ T. Manteuffel, M. Serejski, Polskie Towarzystwo Historyczne (1886-1956), w: Polskie Towarzystwo Historyczne 1886-1956. Ksiega pamiatkowa z okazji zjazdu jubileuszowego PTH w Warszawie 19-21. X. 1956, red. S. Herbst, I. Pietrzak-Pawłowska, Warszawa 1958, s. 5-6. Por. S. Brzozowski, Towarzystwa naukowe we Lwowie..., s. $340-341$.

${ }^{83}$ A. Toczek, Lwów - historycy $w$ działalności towarzystw naukowych miasta (1867-1918), w: Wielokulturowe środowisko historyczne..., t. 5, s. 217.

${ }^{84} \mathrm{Na}$ temat kontaktów naukowych Towarzystwa Historycznego pisze nieco A. Galos, Powstanie Towarzystwa Historycznego i jego organu naukowego, w: Polskie 
tych placówek. Dość skromne informacje posiadamy także na temat wpływu TH na integrację historyków lwowskich z krakowskimi, co miało miejsce poprzez założenie w Krakowie Koła Towarzystwa ${ }^{85}$.

Dużą lukę w badaniach nad kontaktami naukowymi TH wypełnił w pewnym stopniu Roman Masyk, który przedstawił w swoim artykule sieć powiązań łączących polskich i ukraińskich historyków lwowskich $^{86}$. Zdaniem Masyka TH obok Towarzystwa Archeologicznego Krajowego i Towarzystwa Ludoznawczego odegrało istotna rolę w inicjowaniu i umacnianiu relacji naukowych między tymi historykami, stając się dla nich swoistą areną dyskusji na temat wspólnych dziejów. Sprzyjały temu przede wszystkim cele TH, ukierunkowane właśnie na współpracę z różnymi narodami oraz zbadanie przeszłości Rusi Czerwonej. Wyniki swoich badań z tego zakresu historycy polscy i ukraińscy publikowali na łamach KH. Wątek współpracy ukraińskich uczonych z TH opisała też w niewielkim artykule Lidija Łazurko, która doszła do podobnych wniosków co Masyk ${ }^{87}$.

Artykuł Masyka dotyczy ponadto wzajemnych relacji, jakie zachodziły między polskimi i ukraińskimi historykami lwowskimi na forum Towarzystwa Archeologicznego Krajowego i Towarzystwa Ludoznawczego. W przypadku pierwszego z nich, działajacego w latach 18751886, zrealizowane zostało jedno z najważniejszych wspólnych przedsięwzięć naukowych polskich i ukraińskich historyków, a mianowicie Towarzystwo zorganizowało w 1885 r. polsko-ukraiński Zjazd Archeologiczny, który był dobrym przykładem dla kolejnych tego typu inicjatyw $^{88}$. Dobrze rozwijała się także współpraca wspomnianych historyków

Towarzystwo Historyczne 1886-1986, red. S.K. Kuczyński, Wrocław 1990, s. 87. Z kolei o współpracownikach KH pisze E. Barwiński, Towarzystwo Historyczne 1901-1914, KH 51, 1937, z. 1-2, s. 31-36.

${ }^{85}$ E. Barwiński, dz. cyt., s. 26-27.

${ }^{86}$ R. Masyk, Kontakty polskich naukowych towarzystw historycznych Lwowa $z$ historykami Ukraincami od końca XIX do lat 30. XX wieku, w: Poznańskie Towarzystwo Przyjaciót Nauk a towarzystwa naukowe...

${ }^{87}$ Л. Лазурко (L. Łazurko), Співпраия украӥнських учених з Польськиил історичним товариством (львівський період) [Współpraca ukraińskich uczonych z Polskim Towarzystwem Historycznym (okres lwowski)], w: Wielokulturowe środowisko historyczne..., t. 5, s. 240-254.

${ }^{88}$ Nie wiadomo dokładnie, kiedy Towarzystwo Archeologiczne Krajowe zakończyło swoją działalność. Polskie opracowania podają r. 1886, zaś Masyk - r. 1890. Zob. W. Muszyński, Polskie towarzystwa naukowe i wspierajace nauke we Lwowie w latach 1867-1939, „Nauka Polska. Jej Potrzeby, Organizacja i Rozwój” 10, 2001, s. 86; S. Brzozowski, Towarzystwa naukowe we Lwowie..., s. 349. Należy odnotować, że Towarzystwo Archeologiczne, choć nie funkcjonowało zbyt długo, zdołało nawiązać kontakty z wieloma pokrewnymi sobie instytucjami (podaję za: W. Muszyński, dz. cyt., 
lwowskich w ramach drugiego z omówionych przez Masyka towarzystw, czyli Towarzystwa Ludoznawczego (1895), zajmującego się polską kulturą ludową oraz kulturą narodów sąsiednich. Autor zaznacza jednak, że współpraca ta w większości polskich towarzystw utrzymała się najwyżej do końca lat 90. XIX w., ponieważ później nastapił już kryzys we wzajemnych stosunkach polsko-ukraińskich, zarówno naukowych, jak i politycznych. Zabrakło trochę w artykule Masyka relacji między polskimi a ukraińskimi towarzystwami naukowymi, które powstały również w dobie autonomii we Lwowie. Temat ten przybliżył nieco w ostatnich latach Leonid Zaszkilniak, który wykazał, że na przełomie XIX i XX w. stosunki między polskimi i ukraińskimi towarzystwami naukowymi nie układały się najlepiej ${ }^{89}$. Warto w przyszłości zgłębić jeszcze tę problematykę, choćby z uwagi na fakt ogólnie słabo opracowanych $\mathrm{w}$ historiografii polskiej ukraińskich towarzystw naukowych. Z polskich zaś towarzystw lwowskich należałoby pod kątem ich kontaktów naukowych przeanalizować dodatkowo: Towarzystwo dla Popierania Nauki Polskiej we Lwowie (1901), Towarzystwo Lekarskie Lwowskie (1877), Polskie Towarzystwo Politechniczne we Lwowie (1877), Towarzystwo Literackie im. Adama Mickiewicza (1886) i Polskie Towarzystwo Filozoficzne $(1904)^{90}$. Osobno przyjrzeć się też można kontaktom Towarzystwa Przyjaciół Nauk w Przemyślu, założonego w 1909 r. na wzór PTPN i TNK z okresu 1856-1872 ${ }^{91}$.

\section{Zabór rosyjski}

Największym i najważniejszym miastem tego zaboru, nie tylko dla rozwoju kultury i nauki, była Warszawa. Jak pamiętamy, od $1800 \mathrm{r}$. funkcjonowało tam pierwsze towarzystwo naukowe na ziemiach polskich pod nazwą Warszawskie Towarzystwo Przyjaciół Nauk, przemianowane w okresie Księstwa Warszawskiego na Królewskie Towarzystwo Przyjaciół Nauk (dalej: KTPN). Po 1815 r. rozwijało ono całkiem

s. 86): Der Adler w Wiedniu, Historischer Verein für Steiermark w Grazu, Herold w Berlinie, Gesellschaft für Pommersche Geschichte und Alterthumskunde w Szczecinie, Araldica Italiana w Pizie i Societa del Gabinetto di Minerva w Trieście.

89 Л. Зашкільняк (L. Zaszkilniak), Стосунки між украӥнськили і польськими історикали на злалі XIX i XX століть [Stosunki pomiędzy ukraińskimi i polskimi historykami na przełomie XIX i XX wieku], w: Wielokulturowe środowisko historyczne Lwowa wXIXiXX w., red. J. Maternicki, L. Zaszkilniak, t. 2, Rzeszów 2004, s. 272-294.

${ }^{90}$ Zob. S. Brzozowski, Towarzystwa naukowe we Lwowie..., s. 338-360; W. Muszyński, dz. cyt., s. 72-148.

${ }^{91}$ W. Rolbiecki, dz. cyt., s. 182-183. 
dobrze swoją działalność naukowa, która stała na coraz wyższym poziomie dzięki ogólnemu wzrostowi środowiska naukowego Warszawy i otwarciu w tym mieście w 1818 r. uniwersytetu. Najpoważniejszym utrudnieniem w swobodnym rozkwicie myśli naukowej wyrażanej na forum Towarzystwa i w pracach jego członków była cenzura rosyjska. Ingerowała ona np. w sprawe sprowadzania czasopism zagranicznych do biblioteki Towarzystwa. Mogło to rzutować w pewnym stopniu na kontakty naukowe KTPN, które zarówno z instytucjami czy badaczami polskimi, jak i zagranicznymi były dosyć słabe. Wyjątek stanowiły tutaj bardzo dobre relacje Towarzystwa z Uniwersytetem Warszawskim. Wystarczy wspomnieć, że $80 \%$ profesorów Uniwersytetu Warszawskiego należało do Towarzystwa i ściśle z nim współpracowało ${ }^{92}$. Co ciekawe, właściwym inicjatorem szeroko zakrojonych planów badawczych warszawskich uczonych było właśnie Towarzystwo. Warto dodać, że współpraca między obu tymi warszawskimi instytucjami jest już w dużej części opracowana ${ }^{93}$. Kolejnymi ważnymi dla KTPN partnerami na ziemiach polskich były dwa inne ośrodki uniwersyteckie, wileński i krakowski, ale związki z nimi sprowadzały się właściwie do powoływania niektórych tamtejszych profesorów na członków Towarzystwa. W sumie można więc powiedzieć, że Towarzystwo warszawskie, choć aspirowało do bycia instytucja ogólnopolska, w rzeczywistości opierało swoją działalność głównie na członkach miejscowych. Gwoli ścisłości trzeba jednak podkreślić, że inspirowało ono i oddziaływało na różne zamiejscowe środowiska naukowe, które zakładały analogiczne towarzystwa w swoich miastach, np. Towarzystwo Przyjaciół Nauk w Lublinie czy Towarzystwo Naukowe w Płocku ${ }^{94}$. W miarę możliwości starało się też KTPN integrować i pobudzać do pracy twórczej najróżniejszych uczonych na ziemiach polskich, m.in. poprzez ogłaszanie konkursów na rozprawy naukowe, ale rzadko kiedy przynosiły te działania pożądany rezultat.

Umiarkowany zasięg miały także stosunki KTPN z nauką zagraniczna. Opisał je dotąd najszerzej Jerzy Michalski, zwracając uwagę, że ograniczały się one przede wszystkim do wymiany wydawnictw oraz powoływania na członków Towarzystwa wyróżniających się uczonych

${ }^{92}$ M. Wawrykowa, Uniwersytet Warszawski w latach 1816-1831, w: Dzieje Uniwersytetu Warszawskiego 1807-1915, red. S. Kieniewicz, Warszawa 1981, s. 142.

${ }^{93}$ Zob. J. Bieliński, Królewski Uniwersytet Warszawski (1816-1831), t. 3, Warszawa 1912, s. 727, 735-738; M. Wawrykowa, dz. cyt., s. 142-151; J. Miziołek, Uniwersytet Warszawski: dzieje i tradycja, Warszawa 2005, s. 64-65.

${ }^{94}$ Więcej na temat kontaktów naukowych KTPN w Warszawie z podobnymi do niego instytucjami z innych miast pisze J. Michalski, dz. cyt., s. 70-73. 
zagranicznych, jak choćby Vaclava Hanki, Jozefa Šafárika czy Alexandra Humboldta ${ }^{95}$. Wśród instytucji zagranicznych współpracujących z Towarzystwem znalazły się m.in. Królewskie Towarzystwo Czeskie, Muzeum Narodowe w Pradze, Wolne Stowarzyszenie Przyjaciół Literatury Rosyjskiej, uniwersytet kazański czy redakcja „Revue Encyclopédique" 96 . Dobrze zapowiadające się i mające już duży dorobek naukowy KTPN w Warszawie zostało zlikwidowane przez władze rosyjskie w 1831 r. w ramach represji po powstaniu listopadowym. Bogate zbiory Towarzystwa Rosjanie wywieźli w latach 1832-1834 do Petersburga, gdzie zasiliły Cesarską Bibliotekę Publiczną i Cesarską Akademię Sztuk Pięknych.

Oprócz KTPN ton życiu umysłowemu w Warszawie nadawał także nowo ustanowiony w 1816 r. przez cara Aleksandra I uniwersytet, który w 1817 r. otrzymał oficjalną nazwę Królewski Uniwersytet Warszawski $^{97}$. Swoją działalność rozpoczał on jednak dopiero w maju 1818 r., gdy zakończyła się ostatecznie jego organizacja. Składało się na niego pięć wydziałów: Teologiczny, Prawa i Administracji, Lekarski, Filozoficzny oraz Nauk i Sztuk Pięknych. Celem Uniwersytetu było wykształcenie szeroko rozumianych urzędników dla Królestwa Polskiego, w tym prawników, lekarzy i nauczycieli. Początkowo Uniwersytet cieszył się dużą niezależnością oraz swobodą w dziedzinie nauczania, nadawania stopni naukowych i prowadzenia badań naukowych. Językiem wykładowym dla przeważającej liczby przedmiotów był język polski. Obok niego obowiązywała jeszcze łacina, szczególnie na teologii, filologii, medycynie, prawie i filozofii. Od $1820 \mathrm{r}$. władze rosyjskie coraz bardziej ingerowały w organizację Uniwersytetu, co osiagnęło punkt kulminacyjny w 1826 r., kiedy to doszło właściwie do zniesienia autonomii uczelni ${ }^{98}$. Wówczas bowiem pierwszy rektor Uniwersytetu Wojciech A. Szweykowski przestał być rektorem z wyboru, a został mianowany przez władze rosyjskie.

Jeśli chodzi o kontakty naukowe Uniwersytetu $\mathrm{z}$ innymi odpowiadającymi mu instytucjami, to najwięcej informacji mamy o związkach, jakie łączyły go z KTPN oraz z uniwersytetami krakowskim i wileńskim ${ }^{99}$. Poza tym problematyka ta jest zupełnie dotąd niezbadana. Wiąże się ona niewątpliwie z polityką stypendialną Uniwersytetu,

\footnotetext{
${ }_{95}$ Tenże, $Z$ dziejów Towarzystwa Przyjaciót Nauk, Warszawa 1953, s. 277-300.

${ }_{96}$ Tenże, Warunki rozwoju nauki polskiej..., s. 70-72.

${ }^{97}$ M. Wawrykowa, dz. cyt., s. 66.

98 Tamże, s. 71, 82.

${ }^{99}$ J. Bieliński, Królewski Uniwersytet Warszawski..., t. 3, s. 734-752.
} 
o której wspomniał nieco w swojej książce Jerzy Miziołek ${ }^{100}$. Pozostali autorzy piszacy o dziejach Uniwersytetu Warszawskiego nie zwrócili specjalnie uwagi na tę kwestię. Być może wynikało to z faktu krótkiego funkcjonowania Uniwersytetu, który podobnie jak KTPN został zamknięty w $1831 \mathrm{r}$. na skutek represji po powstaniu listopadowym. Duża część zbiorów Uniwersytetu wywieziona została następnie przez władze rosyjskie do Petersburga ${ }^{101}$.

Likwidacja w jednym roku Uniwersytetu Warszawskiego i KTPN doprowadziła do zupełnej stagnacji w życiu naukowym miasta. Jedyna instytucją naukowa, która przetrwała represje władz rosyjskich i kontynuowała po upadku powstania listopadowego swoją działalność, było Warszawskie Towarzystwo Lekarskie. Powstało ono w 1820 r. i skupiało najlepszych medyków warszawskich, spośród których wielu przejawiało ambicje naukowe. Towarzystwo stworzyło z czasem własna bibliotekę i rozpoczęło wydawanie od 1837 r. periodyku o nazwie „Pamiętnik Towarzystwa Lekarskiego”. Mogło się też poszczycić sporą liczbą członków korespondentów, którzy jednakże sporadycznie podejmowali z nim współpracę. W 1850 r. do Towarzystwa włączono jeszcze znanych w mieście farmaceutów. Towarzystwo działało nieprzerwanie do $1939 \mathrm{r}$. O jego trwałości zdecydowały niewątpliwe względy praktyczne, zwiazane z koniecznością utrzymania dobrego stanu sanitarnego miasta ${ }^{102}$.

Kiepskie warunki dla uprawiania nauki, jakie panowały w Warszawie po 1831 r., uległy pewnej poprawie w wyniku klęski Rosji w wojnie krymskiej i śmierci cara Mikołaja I w 1855 r. Udało się wówczas na fali nieco łagodniejszego kursu polityki rosyjskiej względem Królestwa Polskiego otworzyć w 1857 r. Akademię Medyko-Chirurgiczna, będąca namiastką wyższej uczelni w Warszawie. Miała ona charakter polski, ponieważ wykładano w niej po polsku oraz obsadzono ją miejscowymi polskimi kadrami. Istniała zaledwie pięć lat, gdyż w 1862 r. włączona została jako Wydział Lekarski do nowo powstałej w Warszawie Szkoły Głównej, będącej bardziej już rozbudowaną uczelnią wyższa. W jej skład wchodziły bowiem cztery wydziały: Lekarski, Prawa i Administracji, Matematyczno-Fizyczny i Filologiczno-Historyczny. Szkoła miała autonomię i podobnie jak Akademia Medyko-Chirurgiczna kształciła młodziė $\mathrm{w}$ języku polskim, gromadząc w swoich murach polskich profesorów. W konsekwencji Szkoła przyczyniła się znacząco do wzrostu nauki polskiej. Funkcjonowała 7 lat, do 1869 r.,

100 J. Miziołek, Uniwersytet Warszawski..., s. 120-121.

${ }^{101}$ Zob. J. Skowronek, Od likwidacji Uniwersytetu do Akademii Medyko-Chirurgicznej (1831-1857), w: Dzieje Uniwersytetu Warszawskiego..., s. 206.

${ }^{102}$ J. Michalski, Warunki rozwoju nauki polskiej..., s. 185-186. 
gdy na skutek popowstaniowych zaostrzeń w polityce caratu została zamknięta. Trudno mówić w przypadku obu omówionych tutaj szkół o ich kontaktach naukowych, bo działały one zbyt krótko. Nie ma też właściwie informacji na ten temat w dotychczasowej literaturze.

W miejsce rozwiązanej Szkoły Głównej władze rosyjskie utworzyły Cesarski Uniwersytet Warszawski, który odpowiadał swoim ustrojem zreformowanemu w 1863 r. systemowi uniwersytetów rosyjskich. Tym samym nowy Uniwersytet Warszawski wpisywał się w szerszą politykę władz carskich, zmierzających do rusyfikacji Królestwa Polskiego oraz włączenia go w jednolita strukturę Imperium Rosyjskiego. Celem Cesarskiego Uniwersytetu Warszawskiego było kształcenie dzieci urzędników rosyjskich napływających w coraz większej liczbie do Królestwa Polskiego i rusyfikowanie jednocześnie młodzieży polskiej. Proces rusyfikacji zachodził jednak na Uniwersytecie stopniowo, ponieważ brakowało z początku w jego murach rosyjskojęzycznych wykładowców. Równocześnie ubywało wyraźnie polskich pracowników naukowych $^{103}$. Pod względem organizacyjnym Uniwersytet składał się, tak samo jak Szkoła Główna, z czterech wydziałów: Matematyczno-Fizycznego, Medycznego, Historyczno-Filologicznego i Prawnego. W myśl ukazu założycielskiego Uniwersytetu nie można było tworzyć na nim towarzystw naukowych, nadawać doktoratów honorowych i powoływać członków honorowych, co mogło mieć istotny wpływ na ograniczenie aktywności naukowej uczelni ${ }^{104}$. Nie sprzyjało to również rozwojowi kontaktów naukowych Uniwersytetu, o których do tej pory wiemy bardzo mało. Warto jeszcze podkreślić, że mimo rusyfikacyjnych tendencji obecnych na uczelni była ona, przynajmniej do końca XIX w., ważnym miejscem kształtowania się inteligencji polskiej Warszawy ${ }^{105}$.

Gorzej wyglądała natomiast sytuacja z uczonymi polskimi, którzy najpierw po zlikwidowaniu Królewskiego Uniwersytetu Warszawskiego i KTPN, a następnie krótko istniejącej Szkoły Głównej nie mieli żadnego oparcia instytucjonalnego dla swojej pracy. Pustkę w tym zakresie próbowała wypełnić jako pierwsza redakcja pisma literacko-naukowego pt. „Biblioteka Warszawska”, ukazujacego się od $1841 \mathrm{r}$. Pismo to odegrało szczególną rolę w dziejach kultury i nauki polskiej, ponieważ działania jego redakcji wykraczały zdecydowanie poza tradycyjne prace tego typu gremiów. W końcu lat 50. XIX w. doprowadziła ona do przekształcenia „Biblioteki Warszawskiej” w periodyk naukowy. Powołała

${ }^{103}$ I. Ihnatowicz, Uniwersytet Warszawski w latach 1869-1899, w: Dzieje Uniwersytetu Warszawskiego..., s. 419-423.

104 Tamże, s. 388-389.

105 Tamże, s. 490-494. 
także do życia w 1859 r. specyficzną strukturę organizacyjną wokół pisma, której nadano nazwę Współpracownictwa Naukowego Redakcji Biblioteki Warszawskiej. Kryły się pod nią cztery wydziały naukowe: Historyczny, Literacko-Filozoficzny, Nauk Społecznych i Nauk Przyrodniczych, mające za zadanie śledzenie postępów nauki w poszczególnych dziedzinach wiedzy oraz inspirowanie w miarę możliwości badań naukowych. W 1862 r. redakcja czasopisma wystapiła do władz Królestwa z pomysłem przekształcenia stworzonych przez nią wydziałów w oficjalne towarzystwo naukowe o nazwie Towarzystwo Przyjaciół Nauk ${ }^{106}$. Pomysł ten nie spotkał się jednak z aprobatą władz, a jakiekolwiek szanse na jego realizację przekreślił ostatecznie wybuch powstania styczniowego.

Więcej szczęścia mieli inicjatorzy dwóch innych polskich instytucji naukowych, a mianowicie Muzeum Przemysłu i Rolnictwa, założonego w 1875 r., oraz Kasy im. Mianowskiego, powstałej w 1881 r. Obie instytucje prowadziły znacznie szerszą działalność, niż wynikałoby to z ich nazwy. W przypadku Muzeum Przemysłu i Rolnictwa nie była to tylko działalność muzealna, która notabene do 1900 r. wypadała dosyć słabo, ale przede wszystkim oświatowa i badawcza. W siedzibie Muzeum prowadzono bowiem liczne kursy zawodowe, które przekształcały się niekiedy w specjalistyczne szkoły, oraz organizowano odczyty naukowe i popularnonaukowe. Tworzono tam również polskie placówki badawcze, takie jak choćby: stacja meteorologiczna, pracownia chemiczna, fizyczna, geologiczna czy antropologiczna. Muzeum zgromadziło przy tym własny bogaty księgozbiór. Funkcjonowało nadal po I wojnie światowej, ale w zmienionej już formie ${ }^{107}$.

Druga z wymienionych tu instytucji - Kasa Pomocy dla Osób Pracujących na Polu Naukowym imienia dra medycyny Józefa Mianowskiego, bo tak brzmiała pełna jej nazwa, miała na celu uczczenie pamięci Józefa Mianowskiego, zasłużonego rektora Szkoły Głównej, zmarłego w 1879 r. Wprawdzie pierwotnym zamysłem twórców Kasy było utworzenie na cześć Mianowskiego towarzystwa naukowego, ale w związku z tym, że władze rosyjskie nie wyraziły na to zgody, zdecydowano się ostatecznie na rodzaj towarzystwa pomocy naukowej czy kasy zapomogowo-pożyczkowej. Zadaniem Kasy im. Mianowskiego było więc, zgodnie z jej statutem, „udzielanie zapomóg pieniężnych, jednorazowych lub periodycznych, oraz pożyczek osobom pracującym

${ }^{106}$ J. Michalski, Warunki rozwoju nauki polskiej..., s. 227.

${ }^{107}$ S. Brzozowski, Muzeum Przemystu i Rolnictwa $w$ Warszawie, w: Historia nauki polskiej..., t. 4, cz. 1-2, s. 438-445. 
na polu naukowym”. Fundusze Kasy mogły być przeznaczane zarówno na badania i wydawnictwa naukowe, jak i na wsparcie uczonych znajdujących się w złych warunkach materialnych. Dotkliwym ograniczeniem tak prowadzonej działalności Kasy był zakaz władz rosyjskich udzielania pomocy obcym poddanym lub poddanym rosyjskim przebywającym za granica bez zezwolenia rządu. Nie miała też Kasa możliwości inicjowania badań naukowych, choć bardzo do tej roli aspirowała. Starała się zresztą w różny sposób wykraczać poza narzucone jej przez władze ramy aktywności, obejmując swoją opieką wszystkie ziemie polskie i zjednując sobie do współpracy uczonych z pozostałych zaborów $^{108}$. Jak wyglądały dokładnie kontakty naukowe, które utrzymywała Kasa, opisał w swoich pracach Jan Piskurewicz ${ }^{109}$. Autor ten odniósł się także, w osobnym artykule, do relacji naukowych łączących Kase z PTPN ${ }^{110}$. Stwierdził $\mathrm{w}$ nim od razu, że relacje te były bardzo wątłe, co wynikało $\mathrm{z}$ zasadniczych różnic $\mathrm{w}$ organizacji i charakterze obu tych instytucji. Podkreślił z naciskiem, że zakres możliwych działań PTPN był znacznie szerszy niż Kasy, która mogła jednie finansować badania naukowe, nie zaś je inspirować. Kasa dominowała z kolei nad PTPN liczebnością członków, wyjątkowo wysoka skalą społecznego poparcia oraz poziomem dochodów i wydatków. Punktem wspólnym obu instytucji były ugodowe stanowiska, jakie zajmowały one zazwyczaj wobec władz.

Utworzenie właściwego, niezakamuflowanego towarzystwa naukowego w Warszawie stało się możliwe dopiero po rewolucji 1905 r., która przyniosła rok później liberalizację przepisów o towarzystwach i związkach. Nowe dogodne warunki pozwalające na założenie ogólnego naukowego towarzystwa polskiego wykorzystało 15 wybitnych uczonych warszawskich, którzy w 1907 r. powołali do życia TNW. Wśród nich znaleźli się m.in.: Ignacy Baranowski, Ignacy Chrzanowski, Samuel Dickstein, Władysław Smoleński i Włodzimierz Spasowicz ${ }^{111}$.

${ }^{108}$ Tenże, Kasa imienia Józefa Mianowskiego, w: tamże, s. 429-438.

${ }^{109} \mathrm{~J}$. Piskurewicz, Warszawskie instytucje społecznego mecenatu nauki $w$ latach 1869-1906. Muzeum Przemystu i Rolnictwa i Kasa imienia Mianowskiego, Wrocław 1990; tenże, Sto lat zwiazków TNW z Kasa im. Mianowskiego, w: Towarzystwo Naukowe Warszawskie. Sto lat..., s. 63-70.

110 Tenże, Poznańskie Towarzystwo Przyjaciót Nauk a Kasa imienia Mianowskiego $w$ drugiej połowie XIX i na poczatku XX wieku, w: Poznańskie Towarzystwo Przyjaciót Nauk a towarzystwa naukowe...

${ }^{111}$ Warto zwrócić uwagę, że w gronie owych 15 członków założycieli TNW 8 związanych było z Cesarskim Uniwersytetem Warszawskim. Zob. L. Zasztowt, Towarzystwo Naukowe Warszawskie w I połowie XX w., w: Towarzystwo Naukowe Warszawskie. Sto lat..., s. 31-32. 
Bezpośrednim poprzednikiem Towarzystwa było „nieoficjalne koło warszawskich członków Akademii Umiejętności pod przewodnictwem Tadeusza Korzona" 112 . Towarzystwo warszawskie czerpało też w pewnej mierze z wzorów krakowskich, uznając się jednocześnie za kontynuatora tradycji KTPN. Celem TNW było popieranie i rozwijanie tzw. „czystej nauki”, co pociagało za sobą dość rygorystyczne kryteria w doborze jego członków. Towarzystwo dzieliło się na trzy wydziały: Językoznawstwa i Literatury, Nauk Antropologicznych, Społecznych, Historii i Filozofii oraz Nauk Matematycznych i Przyrodniczych. Szybko rosło w siłę i nabierało charakteru ogólnopolskiego. Niewiele niestety wiadomo o kontaktach naukowych Towarzystwa. Najwięcej na ten temat napisał do tej pory Piskurewicz, wyjaśniając związki TNW z Kasa im. Mianowskiego ${ }^{113}$. Krótkie wzmianki poświęcone temu zagadnieniu oraz relacjom TNW z krakowska AU zawarli także w swoich pracach Bogdan Nawroczyński, a w ślad za nim Joanna Arvaniti i Dorota Pietrzkiewicz ${ }^{114}$. Na ciekawą kwestię, zupełnie dotąd niepodejmowana, zwrócił z kolei uwagę Leszek Zasztowt, wskazując na zaangażowanie polskich pracowników Cesarskiego Uniwersytetu Warszawskiego w tworzenie TNW ${ }^{115}$. Wiele problemów czeka więc jeszcze w tym zakresie na zbadanie.

W zaborze rosyjskim poza Królestwem Polskim życie naukowe toczyło się także na Ziemiach Zabranych, gdzie głównym miastem było Wilno. Historia powstałych tam instytucji naukowych odpowiada w znacznym stopniu losom warszawskich instytucji naukowych. Najważniejszą z nich w Wilnie po rozbiorach Polski była niewątpliwie Akademia Wileńska, czyli Szkoła Główna Litewska, która wznowiła swoja działalność w roku akademickim 1796/1797. Początkowo, za panowania Katarzyny II i Pawła I, Akademia Wileńska podlegała władzy administracyjnej i nie miała specjalnie możliwości rozwoju. Szczególnie niekorzystnie wpływała na nią wówczas cenzura rosyjska. Sytuacja poprawiła się wyraźnie po śmierci Pawła I, gdy tron po nim obją bardziej liberalny, przynajmniej w pierwszym okresie swoich rządów, Aleksander I. W ramach zainicjowanej przez niego reformy szkolnictwa

${ }^{112}$ S. Brzozowski, Towarzystwa i instytucje naukowe i naukowo-zawodowe $w$ Królestwie, w: Historia nauki polskiej..., t. 4, cz. 1-2, s. 484.

${ }^{113}$ J. Piskurewicz, Sto lat zwiazków TNW..., s. 63-70.

${ }^{114}$ B. Nawroczyński, dz. cyt., s. 8-14; J. Arvaniti, D. Pietrzkiewicz, Dzieje Towarzystwa Naukowego Warszawskiego w oparciu o zbiory Archiwum Polskiej Akademii Nauk, w: Stulecie Towarzystwa Naukowego Warszawskiego. Katalog wystawy, Warszawa 2007, s. 13.

${ }^{115}$ L. Zasztowt, dz. cyt., s. 32. 
Akademię Wileńska przekształcono w 1803 r. w Cesarski Uniwersytet Wileński, który uzyskał przy okazji dużą autonomię i zaczął się prężnie rozwijać. Jego cechą charakterystyczną było m.in. otwarcie się na uczonych zagranicznych, którym stworzono bardzo dobre warunki, $\mathrm{w}$ tym finansowe, do obejmowania katedr w Wilnie. Miało to ogromne znaczenie dla kontaktów naukowych Uniwersytetu, wyjątkowo bogatych $\mathrm{w}$ omawianym okresie ${ }^{116}$. Mimo licznych obcojęzycznych profesorów pracujących na uczelni, podstawowym językiem wykładowym był język polski. Dominowała także na Uniwersytecie polska kultura, co sprawiło, że Wilno stało się na początku XIX w. jednym z ważniejszych ośrodków polskości. Rozkwit Uniwersytetu przypadł zwłaszcza na lata 1815-1824, kiedy to wzrosła znacząco liczba studentów i wzmocniła się jeszcze tendencja do podnoszenia poziomu kadry naukowej. Istotną rolę odgrywał również autorytet Uniwersytetu, który oddziaływał w różny sposób na społeczeństwo Wilna. Warto dodać, że Uniwersytet Wileński należał wtedy do największych uczelni państwa rosyjskiego. Nawet po niekorzystnych zmianach dla polskiej nauki, jakie nastapiły na Uniwersytecie od 1824 r., nadal stanowił on ważny ośrodek polskiego życia kulturalnego. Nie zawsze jednak znajdowało to bezpośrednie przełożenie na dobre kontakty naukowe Uniwersytetu Wileńskiego z pozostałymi polskimi ośrodkami naukowymi, co wynikało przede wszystkim $\mathrm{z}$ trudności politycznych. Wprawdzie pisał na ten temat nieco Michalski, ale problematyka ta nie jest jeszcze dobrze opracowana ${ }^{117}$. Podobnie zreszta wygląda sprawa $\mathrm{z}$ zagranicznymi kontaktami uczelni ${ }^{118}$. Jej zamknięcie nastapiło nagle w $1831 \mathrm{r}$. i było przejawem represji po powstaniu listopadowym.

Jedyną instytucją naukowa, która przetrwała w Wilnie te represje, było działające od 1805 r. Wileńskie Towarzystwo Lekarskie. Mogło ono kontynuować swoje prace z tych samych powodów, co Warszawskie Towarzystwo Lekarskie. Kontakty naukowe Wileńskiego Towarzystwa Lekarskiego z przełomu XIX i XX w. opisała dotąd najszerzej Henryka Ilgiewicz, która wskazała, że najściślejsze stosunki utrzymywało to towarzystwo z polskimi instytucjami warszawskimi, takimi jak choćby: Warszawskie Towarzystwo Lekarskie, Uniwersytet Warszawski czy biblioteki i redakcje czasopism lekarskich. Dobre kontakty miało też Towarzystwo z uniwersytetami w Krakowie i Lwowie oraz PTPN. Liczne więzi łączyły je także z rosyjskimi towarzystwami

116 J. Michalski, Warunki rozwoju nauki polskiej..., s. 79.

117 Tamże, s. 113-117.

118 J. Bieliński, Uniwersytet Wileński (1579-1831), t. 3, Kraków 1899-1900, s. $618-624$. 
lekarskimi, rozsianymi po całym Imperium, i medycznymi ośrodkami zachodnioeuropejskimi ${ }^{119}$.

Pewne odrodzenie życia naukowego w Wilnie nastapiło po r. 1855, co związane było ze złagodzeniem kursu politycznego w Rosji po wojnie krymskiej i śmierci cara Mikołaja I. Uaktywnił się wówczas w Wilnie Eustachy Tyszkiewicz, który w 1855 r. utworzył Tymczasową Komisję Archeologiczną połączoną z Muzeum. Warto podkreślić, że pierwotnym zamiarem Tyszkiewicza było stworzenie docelowo ogólnego towarzystwa naukowego, w które próbował później przekształcić Tymczasową Komisję Archeologiczna, ale nie udało mu się tego ostatecznie zrealizować. Sama Komisja działała natomiast, dość intensywnie lobbując m.in. za wskrzeszeniem uniwersytetu w Wilnie. W stosunkowo krótkim czasie nawiązała też ona liczne kontakty naukowe, powołując na swoich członków osoby spoza Wilna i spoza zaboru rosyjskiego. Szczególną wagę przykładała zwłaszcza do kontaktów z uczonymi z krajów słowiańskich, takimi jak choćby Jozef Šafárik czy Vaclav Hanka. W jej szeregach znaleźli się także badacze z Łużyc - Christian Pfuhl i Jan Arnošt Smoler ${ }^{120}$. Mimo rychłego rozwiązania Komisji przez władze w 1865 r. miała ona niemałe znaczenie $\mathrm{w}$ rozwijaniu polskiego ruchu naukowego Wilna.

Kolejne polskie towarzystwo naukowe, z początku nielegalne, powstało w Wilnie w 1899 r. Nosiło ono nazwę Towarzystwo Miłośników Starożytnictwa i Ludoznawstwa. O jego kontaktach naukowych poważnie utrudnionych z powodu tajnej działalności pisała również Ilgiewicz w przywoływanej już wyżej pracy. Autorka zwróciła w niej uwagę na metody, jakie stosowało Towarzystwo, by w trudnej sytuacji pozyskać dla swoich planów współpracowników ${ }^{121}$. Ilgiewicz omówiła także kontakty naukowe założonego w 1899 r. Wileńskiego Oddziału Towarzystwa Krzewienia Rosyjskiej Oświaty Historycznej, który współpracował przede wszystkim z innymi rosyjskimi instytucjami. O ile autorce wiadomo, nie był on zainteresowany relacjami z zagranicznymi towarzystwami ani z polskimi czy litewskimi organizacjami naukowymi utworzonymi w Wilnie po $1907 \mathrm{r} .{ }^{122}$

Jak pamiętamy bowiem, lata 1905-1907 przyniosły korzystne zmiany w polityce wewnętrznej Rosji, umożliwiające zakładanie polskich i litewskich towarzystw naukowych. W Wilnie najważniejszym polskim

${ }^{119}$ Zob. też H. Ilgiewicz, dz. cyt., s. 52-104.

${ }^{120}$ J. Michalski, Warunki rozwoju nauki polskiej..., s. 229-230.

${ }^{121}$ Więcej na temat tego Towarzystwa zob. H. Ilgiewicz, dz. cyt., s. 231-251.

${ }^{122}$ Więcej na temat tego Towarzystwa zob. H. Ilgiewicz, Societates Academicae Vilnenses. Towarzystwo Przyjaciót Nauk w Wilnie (1907-1939) i jego poprzednicy, Warszawa 2008, s. 123-165. 
towarzystwem w owym czasie było niewątpliwie Towarzystwo Przyjaciół Nauk (dalej: TPN), założone w 1907 r. Według statutu miało ono na celu pielęgnowanie nauk, umiejętności i literatury w języku polskim oraz badanie kraju pod względem przyrodniczym, etnograficznym, historycznym, ekonomicznym i statystycznym ${ }^{123}$. Celowo jednak organizatorzy Towarzystwa, z różnych przyczyn, nie użyli w jego nazwie przymiotnika „polskie”, co mogło w pewnym stopniu ułatwić mu kontakty z innymi, niepolskimi instytucjami naukowymi, np. z Litewskim Towarzystwem Naukowym. Było to o tyle ważne, że wileńskie TPN przywiąywało dużą wagę do kontaktów naukowych, prowadząc, jak się wydaje, przemyślana politykę powoływania do niego członków honorowych i korespondentów. Politykę tę opisał nieco w jednym ze swoich artykułów Leszek Zasztowt, zastanawiając się, na ile decyzje o nadaniu członkostwa honorowego i tytułu członka korespondenta Towarzystwa odzwierciedlały rzeczywistą łączność pomiędzy różnymi ośrodkami akademickimi na porozbiorowym obszarze dawnej Rzeczypospolitej ${ }^{124}$. Rozważał także, czy fakt nadania członkostwa honorowego był autentycznym świadectwem związków prowincjonalnego w gruncie rzeczy Wilna $\mathrm{z}$ najwybitniejszymi ówczesnymi autorytetami w nauce europejskiej. W konkluzji stwierdził, że trudno jednoznacznie odpowiedzieć na tak postawione pytania, szczególnie w odniesieniu do członków honorowych Towarzystwa. Klarowniej wyglądała, zdaniem autora, sytuacja z członkami korespondentami TPN, którzy o wiele bardziej angażowali się w jego prace. Warto tu przy okazji wspomnieć, że już w 1908 r. ponad połowa zwyczajnych członków Towarzystwa mieszkała poza Wilnem, co wpływało zapewne korzystnie na rozwijane przez nie kontakty ${ }^{125}$. Dosyć silne były one również z poszczególnymi instytucjami naukowymi, spośród których na pierwszym miejscu wymienia Zasztowt krakowską AU. Nie omawia natomiast relacji TPN z Litewskim Towarzystwem Naukowym, co należałoby jeszcze w przyszłości uczynić. Generalnie problematyka kontaktów TPN w Wilnie nie została dotąd wyczerpana. Prawie żadnych informacji na ten temat nie zawiera obszerna praca Ilgiewicz poświęcona w głównej mierze temu Towarzystwu ${ }^{126}$.

${ }^{123}$ L. Żytkowicz, Towarzystwo Przyjaciót Nauk w Wilnie 1907-1940, w: Z dziejów nauki polskiej, red. A. Hutnikiewicz, L. Janiszewski, Warszawa-Poznań-Toruń 1975, s. 51.

${ }^{124}$ L. Zasztowt, De unitate societatis scientiarum - pomiędzy nauka „narodowa” $a$ „światowa”- utworzenie Towarzystwa Przyjaciót Nauk w Wilnie w kontekście wspótpracy środowisk naukowych przed I wojna światowa, w: Poznańskie Towarzystwo Przyjaciót Nauk a towarzystwa naukowe...

${ }^{125}$ L. Żytkowicz, dz. cyt., s. 53-54.

${ }^{126}$ H. Ilgiewicz, Societates Academicae Vilnenses... 
* * *

Spoglądając całościowo na bogatą problematykę kontaktów między towarzystwami naukowymi na ziemiach polskich w XIX i na początku XX w., trzeba raz jeszcze podkreślić, że była ona do tej pory zupełnie niedoceniana. Wskutek tego nie znalazła właściwie szerszego odzwierciedlenia w literaturze przedmiotu. Tam z kolei, gdzie została przez autorów dostrzeżona, brakuje często właściwego jej zinterpretowania. Najpoważniejszym błędem badaczy jest postrzeganie tej tematyki przez pryzmat jedynie narodowościowy, kojarzony szczególnie w przypadku ziem polskich pod zaborami z rodzącymi się na tym tle konfliktami. Tymczasem właśnie na przykładzie kontaktów między różnymi instytucjami naukowymi działającymi w trzech zaborach widać wyraźnie, jak skomplikowana była to materia i jak różne czynniki odgrywały rolę w nawiązaniu lub zaniechaniu niektórych relacji. Pozostaje więc mieć nadzieję, że przyszłe badania będą w tym zakresie bardziej kompleksowe i przyczynią się do lepszego zrozumienia życia naukowego na ziemiach polskich pod zaborami.

\section{Alina Hinc}

Contacts between academic societies in the lands of partitioned Poland status of and need for research

(Summary)

The article describes contacts between academic societies operating in the lands of partitioned Poland. Its purpose is to present the current status of research on this very wide topic and to indicate the need for research that arises in this respect. A comprehensive view of these contacts shows that the topic has not been acknowledged to-date. Therefore, it has not been properly reflected in the professional literature. Where the topic has been recognized by authors, it has often not been properly interpreted. The most frequent mistake that has been made by researchers is perceiving the issue from an exclusively ethnic angle, which - particularly in respect of the lands of partitioned Poland - is related to the conflicts arising in such conditions. Seen against the background of the contacts between the various academic institutions operating in the three partitions, it is clearly visible how complicated the matter was and how different factors played a role in forming and discontinuing relationships.

Key words: academic associations, academic institutions, universities, contacts, relationships, cooperation, Partitions of Poland, science, Polish lands, scientific studies, history of science 